\title{
EARTHQUAKE OF 7 DECEMBER 1988, SPITAK, ARMENIA REPORT OF THE NZNSEE TEAM VISIT OF 1989
}

\author{
P.R. Wood1, J.B. Berrill'2, N.R. Gillon 3 , P.J. North ${ }^{4}$
}

\section{INTRODUCTION}

\subsection{General}

The Spitak earthquake $\left(\mathrm{M}_{\mathrm{s}} 6.8\right.$, Wylie \& Filson, 1989) occurred on 7 December 1988 and resulted in the reported loss of at least 25,000 lives, an exceptional loss for an earthquake of moderate size. Some 514,000 people were left homeless, 31,000 were injured. The collapse of modern buildings was the principal cause of death and injury.

The New Zealand National Society of Earthquake Engineering approached the Soviet Embassy in Wellington for information on the earthquake and, when the immediate recovery phase was completed, was invited to send a team of earthquake engineers and scientists to learn at first hand of the earthquake and its effects. The team which departed New Zealand on 25 September 1989 comprised R.B. Shephard (Leader) ${ }^{6}$; P.J. North; J.B. Berrill; N.R. Gillon; and P.R. Wood. The Soviet Academy of Science and the Geological Institute of Armenia hosted the team in the Soviet Union. During the journey to and from the Soviet Union the group met with other researchers of the Spitak earthquake in Japan, the U.K. and U.S.A. ${ }^{7}$, to learn more and compare findings.

The following is a summary of information collected on the Spitak earthquake, particularly its geological and seismotectonic setting, the earthquake sequence and its impact. Our hosts in Moscow and Armenia greatly facilitated our visit, but limited time and difficulties in transport to, and within, Armenia made this post earthquake inspection a reconnaissance in nature, even though it took place ten months after the event.

\subsection{Tectonic, seismic and geographic setting}

The Spitak earthquake occurred in the Republic of Armenia, between the Black and Caspian seas, and was located in the Lesser Caucasus highlands (Figure 1), about $80 \mathrm{~km}$ south of the axis of the Greater Caucasus. The Caucasus Mountains

Institute of Geological \& Nuclear Sciences, Lower Hutt (Member).

Department of Civil Engineering, University of Canterbury, Christchurch (Fellow).

3 The Wellington Regional Council, Wellington (Member)

$4 \quad$ Murray-North Ltd, Auckland (Fellow) are uplifted along the broad, compressive, plate boundary region where the Arabian and Eurasian plates collide (Figure 2 ). The region is characterised by mountain ranges, part of the chain running from the European Alps in the west through to the Himalayas in the east.

The historic seismicity of the region can be traced back about 2000 years. Recent epicentre locations are depicted in Figures 3 \& 4. Prior to the Spitak earthquake the region had been zoned by the Soviets for seismic risk (Figure 5) on the basis of the historical seismic record, assigning expected maximum shaking intensities of MSK VII-VIII (the MSK-64 intensity scale approximates to the Modified Mercalli scale commonly used in New Zealand; a description of both scales is given, for example, in Dowrick, 1987). This zoning was based on consideration of the maximum magnitudes and relatively low frequencies of historic earthquakes.

The geography of the epicentral area is shown in Figure 6 . The population of Armenia is approximately 3 million, with a land area of $30,000 \mathrm{~km}^{2}$. Yerevan, the capital, has a population of about 1 million; Leninakan, in the epicentral area, is the next largest city with a population of about 290,000 , while the two other principal cities in the epicentral area are Kirovakan $(170,000)$ and Spitak $(20,000)$. The population of the area affected by the earthquake is about 600,000 . Armenia is bounded to the north and east by the Soviet Socialist Republics of Georgia and Azerbaijan, and to the west and south by Turkey and Iran. There is a long history of conflict between the dominantly Christian Armenia and its Muslim neighbours. Because of recent escalation of civil unrest between Armenians and Azerbaijans, Armenia has had an influx of refugees with some approximately 50,000 reported to have settled in the epicentral region [Pomonis, 1989].

\footnotetext{
References to the former Soviet Union are given as they were at the time of the earthquake, the NZNSEE team visit, and the writing of this report.
}

6 Works Consultancy Services, Wellington.

7 While visiting San Francisco to meet with representatives of EERI, the Loma Prieta earthquake of 17 October 1989 occurred. Subsequent investigation by the NZNSEE team is reported in Shephard et. al., [1990]. The NZNSEE team's involvement in the Loma Prieta earthquake has been the principal cause in the delay in the completion of this report on the Spitak earthquake. 


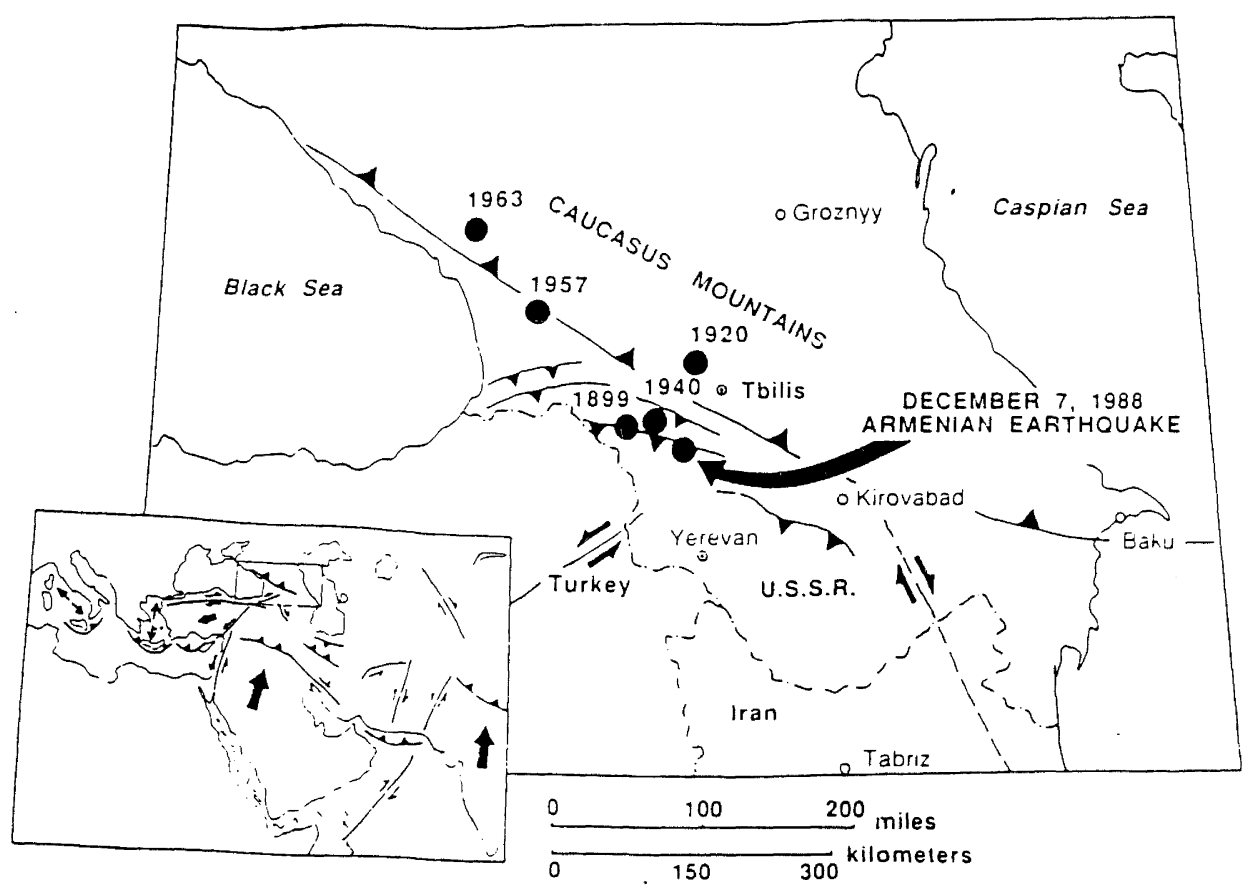

Figure 1 Tectonic setting of the Armenian earthquake. Insert shows the convergence of the Arabian and Eurasian plates in the Caucasus region forming part of a broad band of convergence stretching across southern Europe and Asia. The figure shows major fault trends and the location of the larger earthquakes (all less than magnitude 6.5) within the region. (Prepared by the Lamont-Doherty Geological Obsenvatory) [Wytie and Filsom, 1989]

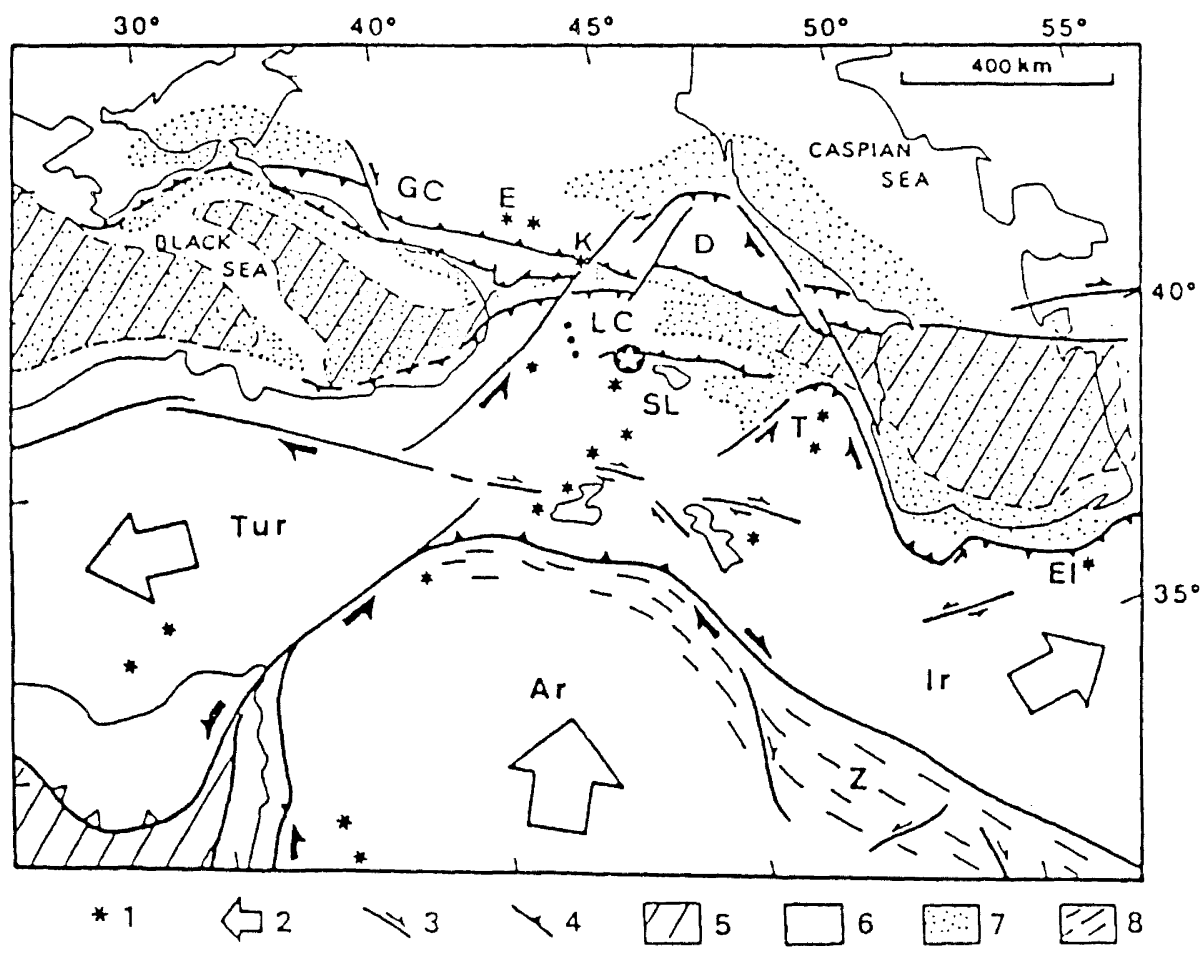

Figure 2 Present day tectonic features characterising the Caucasus. The star shows the epicentre of the 7 December 1988 Armenian earthquake 1, Recent volcanoes; the Aragaat volcano is just below the epicentre 2, Relative motion with respect to Eurasia. 3, Major strike-slip faults. The north east-oriented Borjomi-Kasbeg fault passes next to the Kasbeg volcano. 4, Major thrusts; the Sevan-Akera fault zone passes by the epicentre of the Spitak earthquake. 5, Oceanic or intermediate crust. 6, Continental crust. 7, Main sedimentary basins. \&, Recent folding at the border of the Arabian plate. GC, Great Caucasus; D, Dagestan; LC, Lesser Caucasus; T, Talesh; El, Elbros; Ir, Iranian; Tur, Turkish block; Ar, Arabian plate; Z, Zagros; SL, Sevan Lake; K, Kasbeg volcano; E, Elbruz volcano. [Cirtemas at al, 1989] 


\section{CAUCASUS_historical_M $>5.0$}

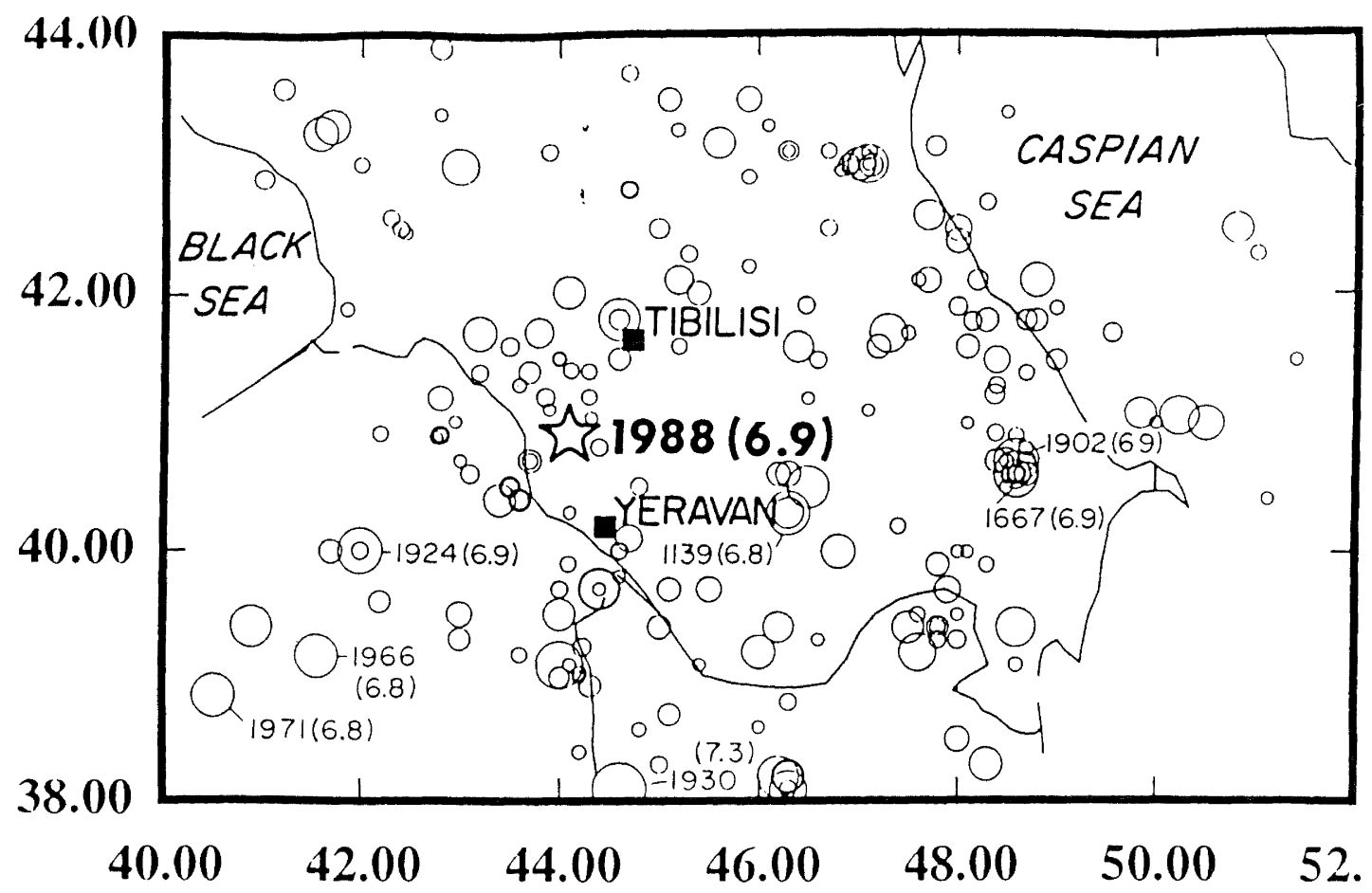

Figure 3 Historical seismicity of the Caucasus region [From Ambraseys and Adams, 1989. Prepared by Lamont-Doherty Geological Observatory]

$$
1962-1987 \quad \mathrm{~m}>2.8
$$

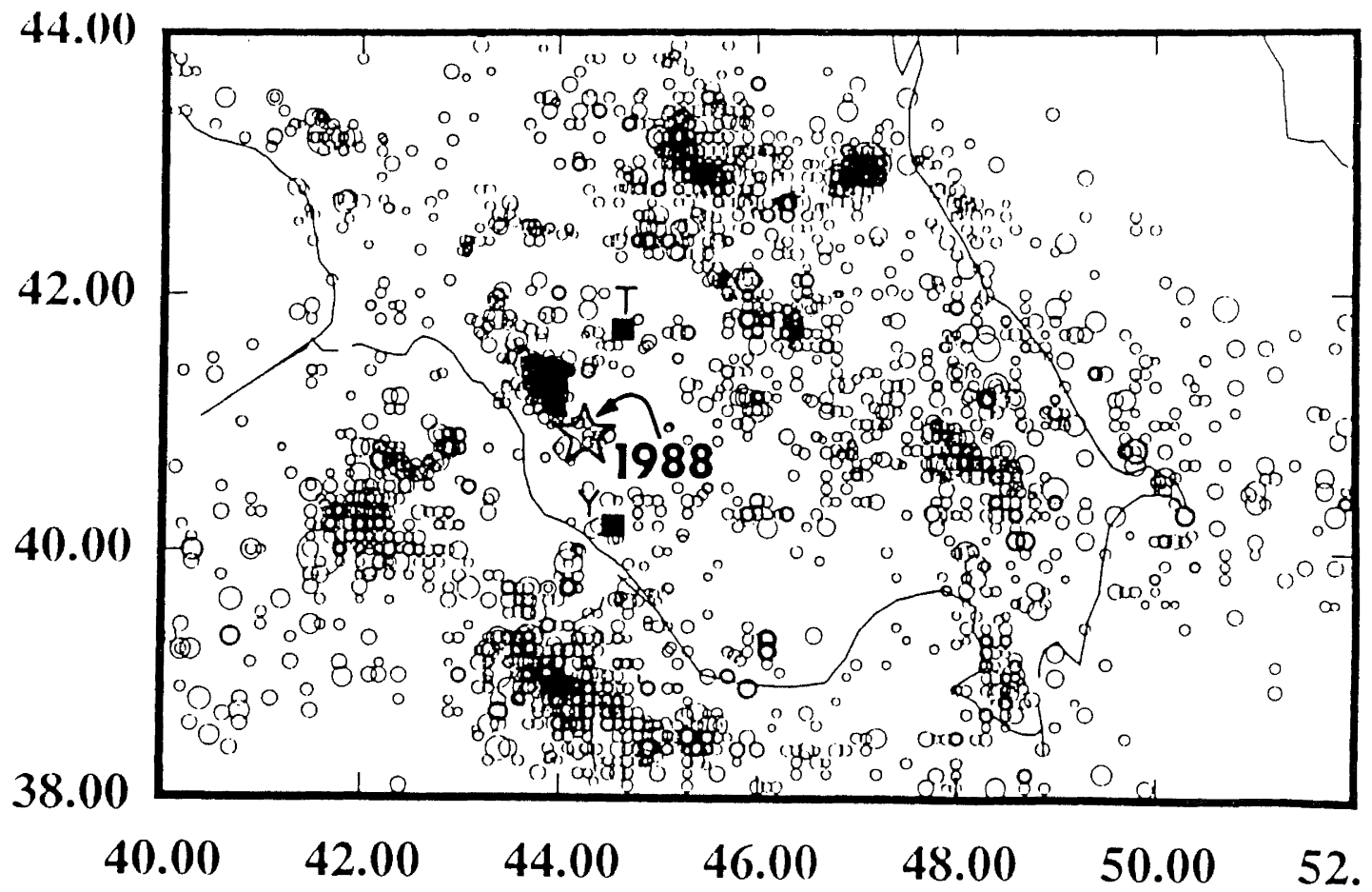

Figure 4 Recent seismicity of the Caucasus region. [From Earthquakes in the USSR, (1987). Prepared by Lamont-Dohenty Geological Observatony] 


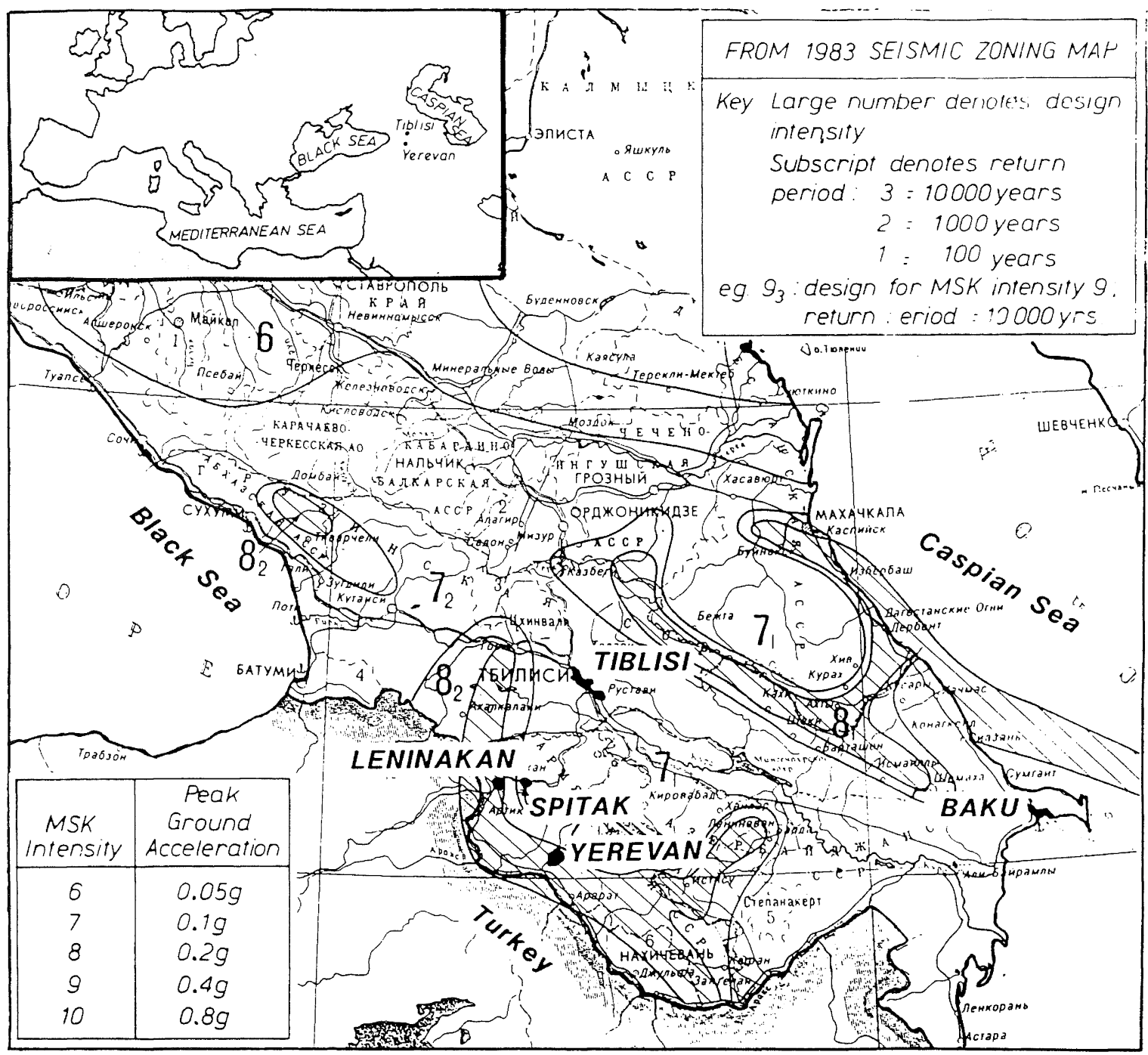

Figure 5 Map of Caucasus Region, showing Soviet seismic design intensities (in the MSK scale).

The border between the Armenia S.S.R. and Turkey is $40 \mathrm{~km}$ from the epicentre of the Spitak earthquake. Deaths, injuries and building damage resulted in Turkey from the earthquake [Dr R. Ates, Western Seismic Group, Turkey; pers. comm.].

\section{SEISMIC DESCRIPTION}

The preliminary reports of epicentre location for the 1988 Spitak earthquake are summarised in Table I. Pacheco et al. [1989] infer, from analysis of teleseismic body waves, an earthquake rupture history with not one event but three subevents, all very similar in size. Nucleation is described 3 seconds before the first subevent which is primarily reverse with a small right slip component, the preferred nodal plane has an attitude of $110 / 44 \mathrm{~N}$, and the centroid depth is $2.5 \mathrm{~km}$. The second subevent is primarily right slip with a small reverse component; it is located at an azimuth of $150^{\circ}$ and $15 \mathrm{~km}$ distant from the nucleation point. It has a preferred attitude of $134 / 83 \mathrm{NE}$, with a depth of $6 \mathrm{~km}$. The third subevent is also right slip with a small reverse component,
$32 \mathrm{~km}$ west of the nucleation point, with a preferred attitude of $089 / 70 \mathrm{~N}$ (no depth given). The three sub event mechanisms are shown in Figure 7, along with the well located aftershocks. A schematic of the rupture process is shown in Figure 8. The total duration of the sequence is less than 20 seconds, which requires a rupture $40-50 \mathrm{~km}$ long. The multiple main event was followed some four minutes later by the largest aftershock of $m_{b} \approx 5.9$. Further analysis of broad-band teleseismic body wave records of the Spitak earthquake sequence is presented by Haessler et al. [1992].

\section{FAULT RUPTURE OF THE GROUND SURFACE}

Initial reports of surface faulting were of some $8-13 \mathrm{~km}$ of rupture with up to $2 \mathrm{~m}$ of reverse-oblique slip [Cisternas et al. 1989 , Sharp (Chapter 2 in Wiley \& Filson 1989)]. Snow that fell after the earthquake limited ground observation at the time.

Subsequently additional field work enabled Tifonov et al. 


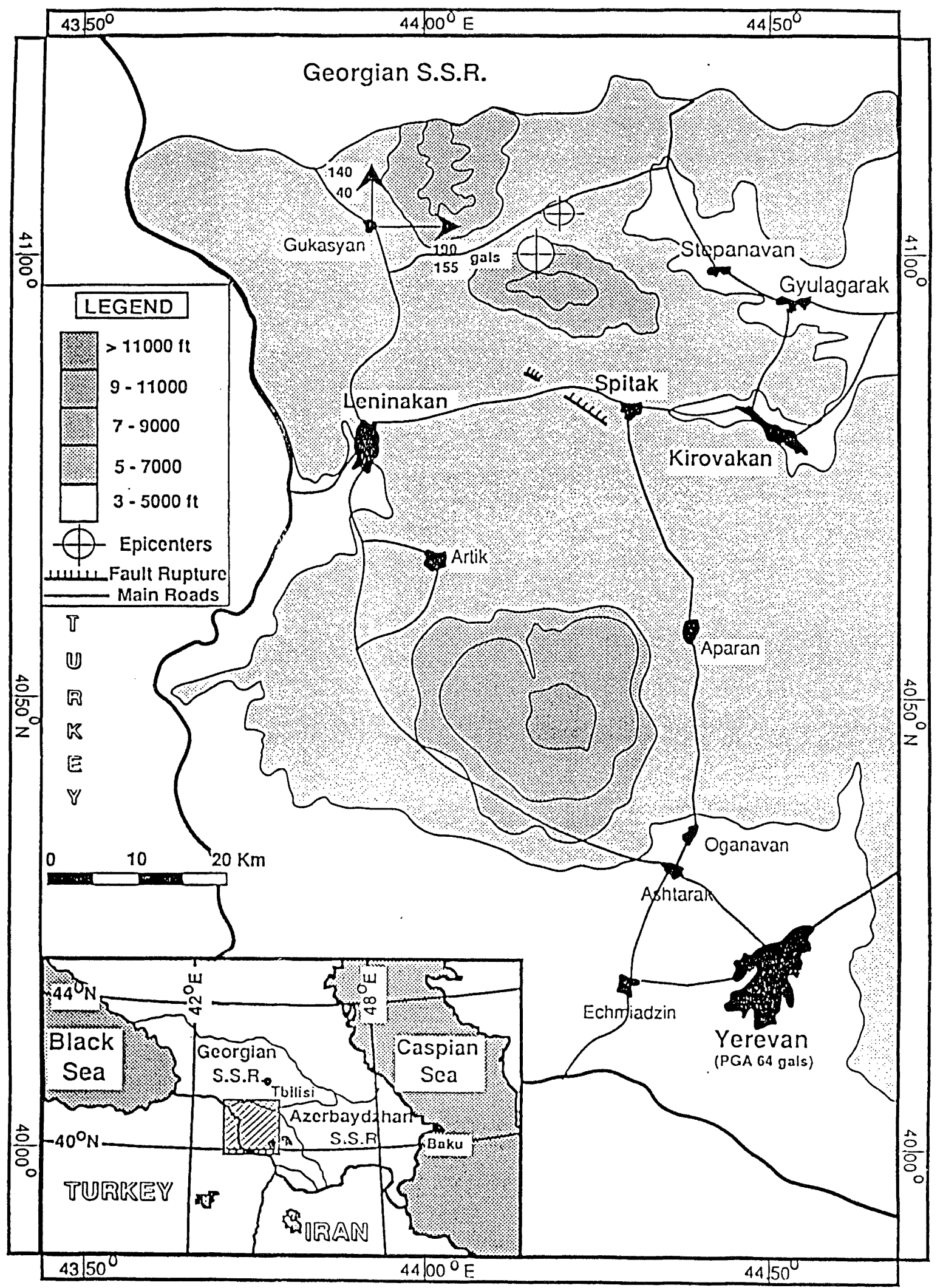

Figure 6 Map of western Armenia showing the epicentral region. [from Pomonis, 1989] 


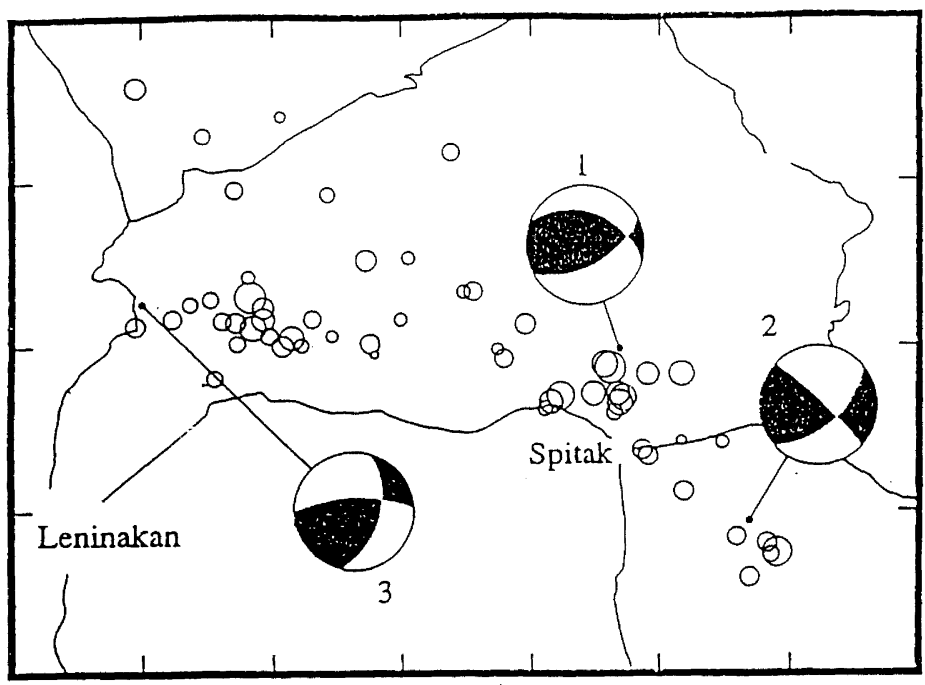

Figure 7 The location of the main shock subevents, towns, roads, and the best located aftershocks recorded by the USGS and the Lamont-Dohenty Geological Observatory. [from Pacheco at al, 1989]

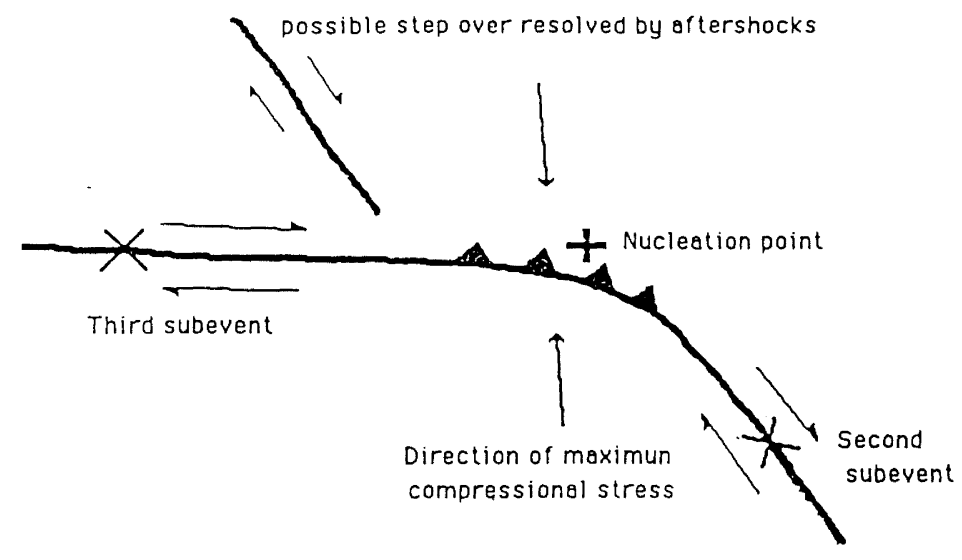

Figure 8 Schematic diagram of nupture process, inferred by Pacheo et al (1989) from teleseismic body waves. [from Pachoco at al, 1989]

Table I. Parameters of the 1988 Spitak earthquake.

\begin{tabular}{|l|l|l||}
\hline & \multicolumn{1}{|c|}{ NEIC USGS } & \multicolumn{1}{c|}{ IPE USSR } \\
\hline $\begin{array}{l}\text { Origin time: } 1988 \\
\text { December 7 }\end{array}$ & $07 \mathrm{hr} 41 \mathrm{~min} 24.96 \mathrm{sec}$ UTC & $07 \mathrm{hr} 41 \mathrm{~min} 24.6 \mathrm{sec}$ UTC \\
\hline Latitude (deg) & $40.996 \mathrm{~N}+/-2.9 \mathrm{~km}$ & $40.92 \mathrm{~N}$ \\
\hline Longitude (deg) & $44.197 \mathrm{E}+/-1.8 \mathrm{~km}$ & $44.20 \mathrm{E}$ \\
\hline Depth & $10 \mathrm{~km}$ (fixed) & $10 \mathrm{~km}$ \\
\hline Magnitudes & $\begin{array}{l}\mathrm{m}_{\mathrm{b}} 6.3 \\
\mathrm{M}_{\mathrm{s}} 6.8 \text { from } 17 \text { obs. } \\
\mathrm{M}_{\mathrm{s}} 7.0 \text { Berkeley }\end{array}$ & 7.0 \\
\hline
\end{tabular}

Wyllie, LA., Filson, J.R, 1989: Armenian earthquake reconnaissance report. Earthquake Spectra, August 1989. 


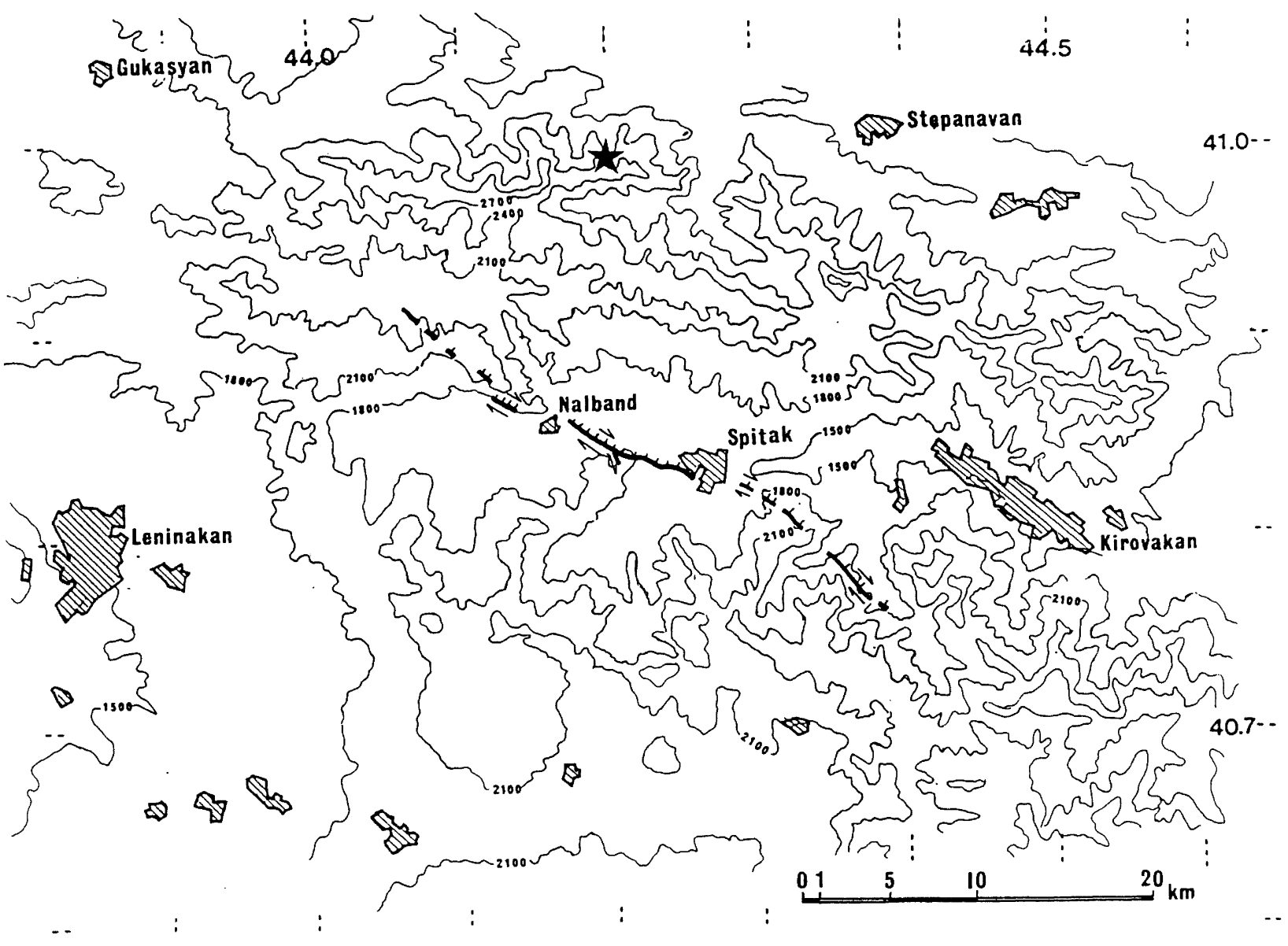

Figure 9 Mapped surface nupture (from Bommar and Ambraseys, 1989)

[1989] and Philip et al. [1992] to document some $40 \mathrm{~km}$ of discontinuous fault trace of variable width, comprised of three apparently separate parts which are nearly collinear (Figure 9). Photographs of the surface expression of the fault ruptures are presented in Figures $10-13$ by courtesy of Dr A. Karakhanian.

The displacement slip vector observed at the ground surface reaches a maximum of 2 metres vertical with up to 1.8 metres right lateral slip recorded by Trifonov $e t$ al, along with fault plane dips of $37-85^{\circ}$.

There is good agreement between the models of the fault geometry derived independently from seismology and surface geology. The geometry of the traces fits the schematic multiple rupture of Pacheco et al. well, accepting that the third subevent is not represented by surface faulting and that the "possible step over" is so expressed, (Figure 8). Philip et al. [1992], conclude that the source was even more complex and consisted of five main branches (Figure 14).

\section{STRONG GROUND MOTION}

Felt intensities compiled by Ambraseys [Bommer \& Ambraseys, 1989], including reports from outside of Armenia, are shown in Figure 15. The maximum assigned intensity assigned is MSK $X$ at Spitak. Observed intensities are compared with design values in Table II.
The nearest instrumental recording of the earthquake was from the town of Gukasyan, about $25 \mathrm{~km}$ away from the fault rupture (Figure 6). The record has been digitised [Bommer \& Ambraseys, 1989] and is shown in Figure 16. Its characteristics are summarised in Table III. A strong motion accelerograph at Stepanovan, about $20 \mathrm{~km}$ from the fault rupture (Figure 6), went off scale, while a Medvedev seismoscope ${ }^{8}$ there recorded $280 \mathrm{~cm} / \mathrm{s}^{2}$.

Although no accelerograms from Leninakan have survived (records from an accelerograph in a 16 storey lift-slab structure were lost in its collapse), instrumental records were obtained from Medvedev seismoscopes and from multipendulum seismometers. Records from five Medvedev seismoscopes gave peak accelerations in the range of 280 to $400 \mathrm{~cm} / \mathrm{s}^{2}$. Multipendulum seismographs belonging to the Leninakan Geophysics Institute recorded the acceleration responses listed in Table IV at various locations in Leninakan.

Estimates of peak accelerations at Spitak, of about 0.6 to $0.7 \mathrm{~g}$, were quoted by various Soviet scientists, but the basis of these estimates is unknown.

Peak accelerations of about $0.06 \mathrm{~g}$ were recorded in Yerevan, $80 \mathrm{~km}$ south of the epicentre.

8 Medvedev seismoscope characteristics are: $T_{n}=0.25 \mathrm{~s}$, $\zeta=0.50$ 


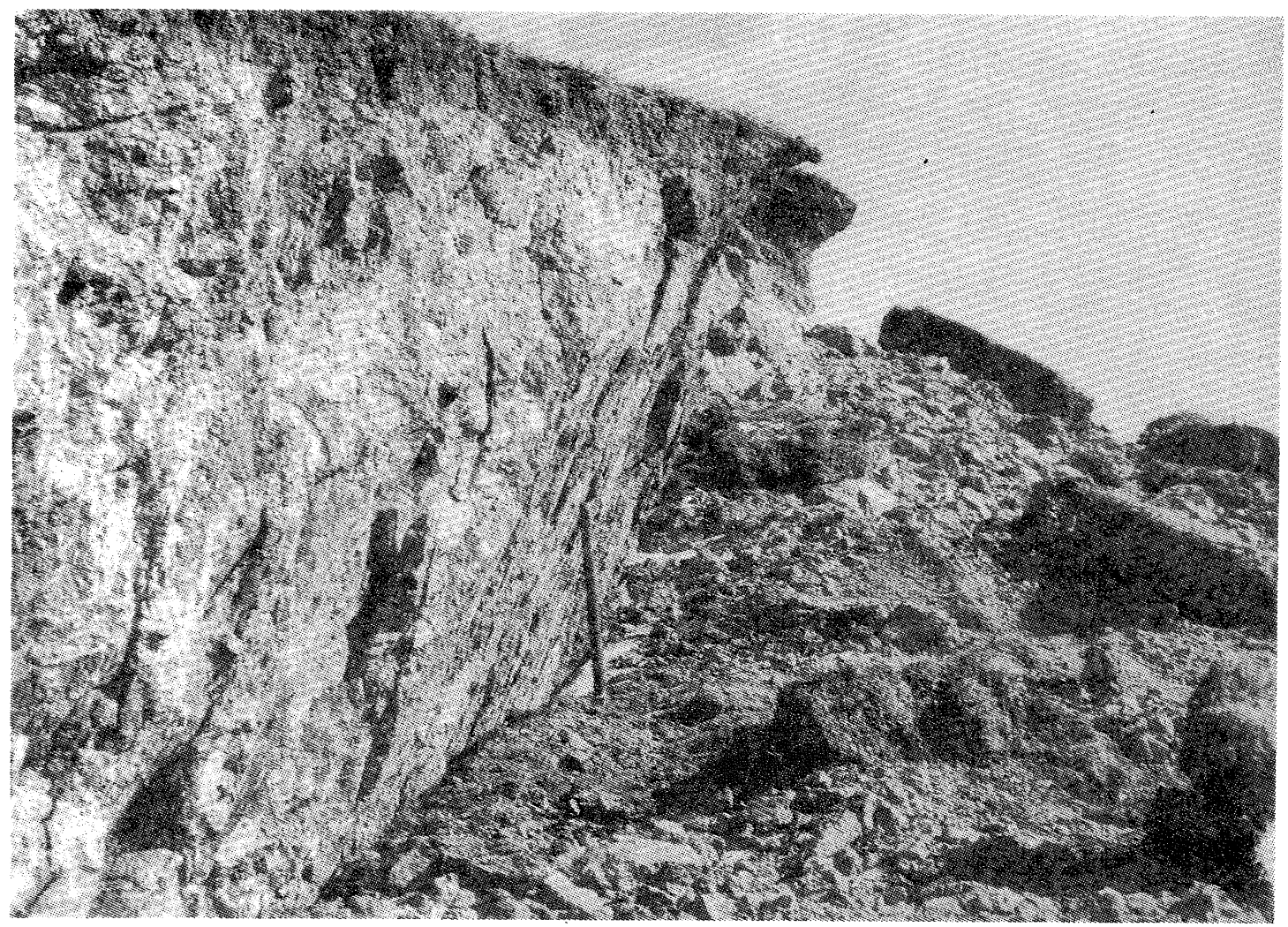

Figure 10 Foult scarp produced by the Spitak earthquake (with hammer for scale). [from Trifonov a al. (1989)]

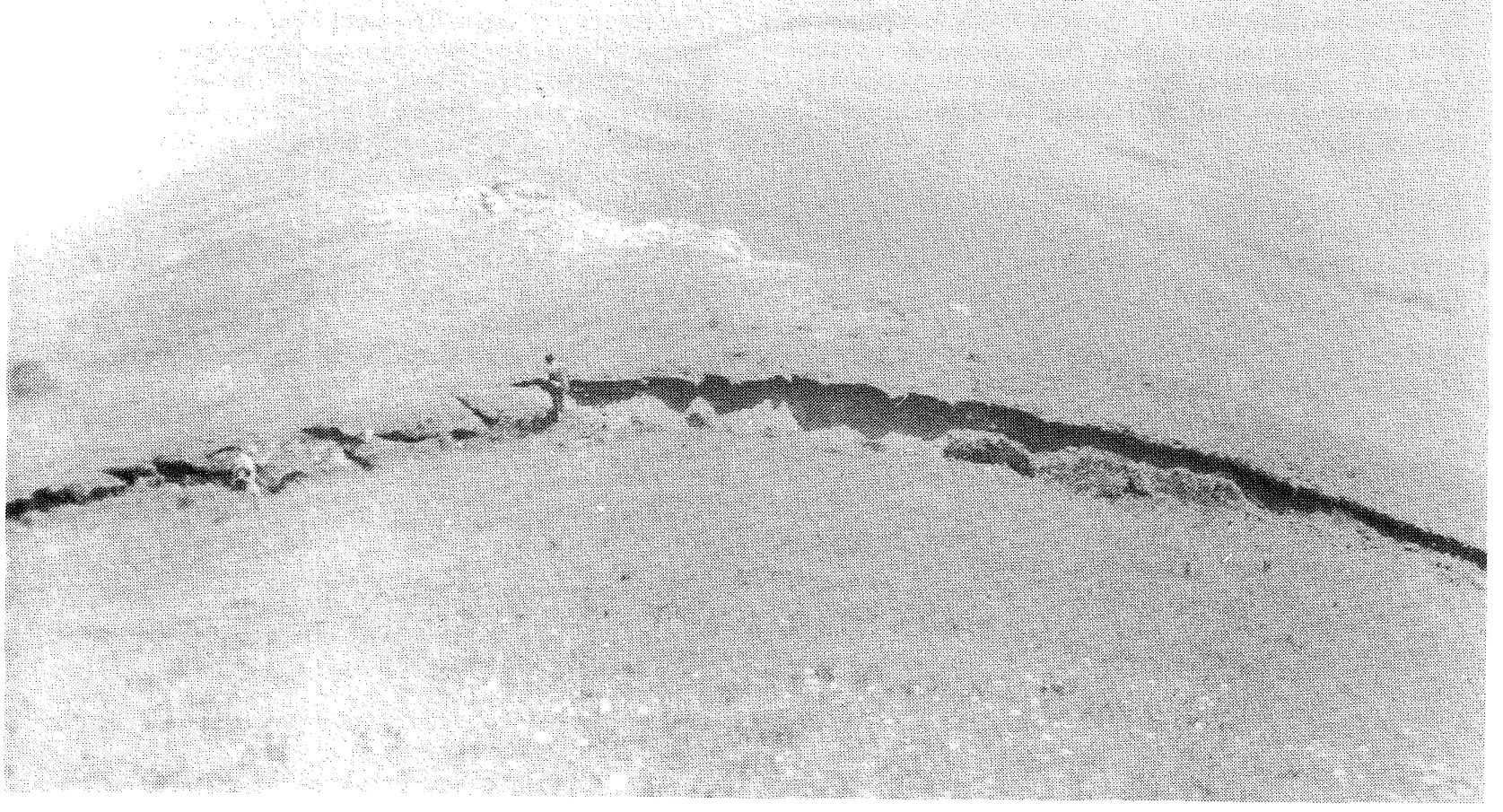

Figure 11 Surface nupture [A. Ranakhanian] 


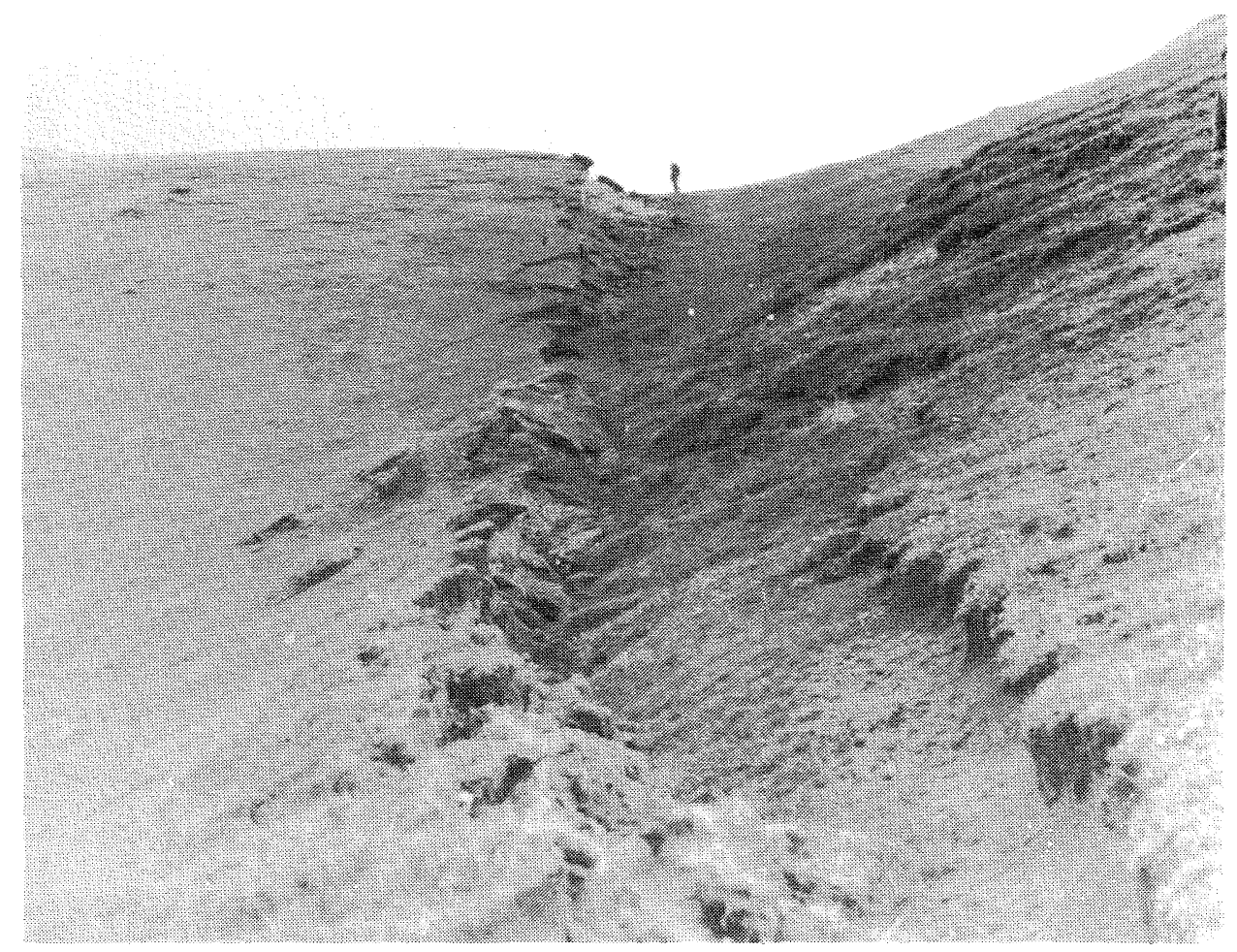

Figure 12 Surface nupture. [A. Karakhenian]

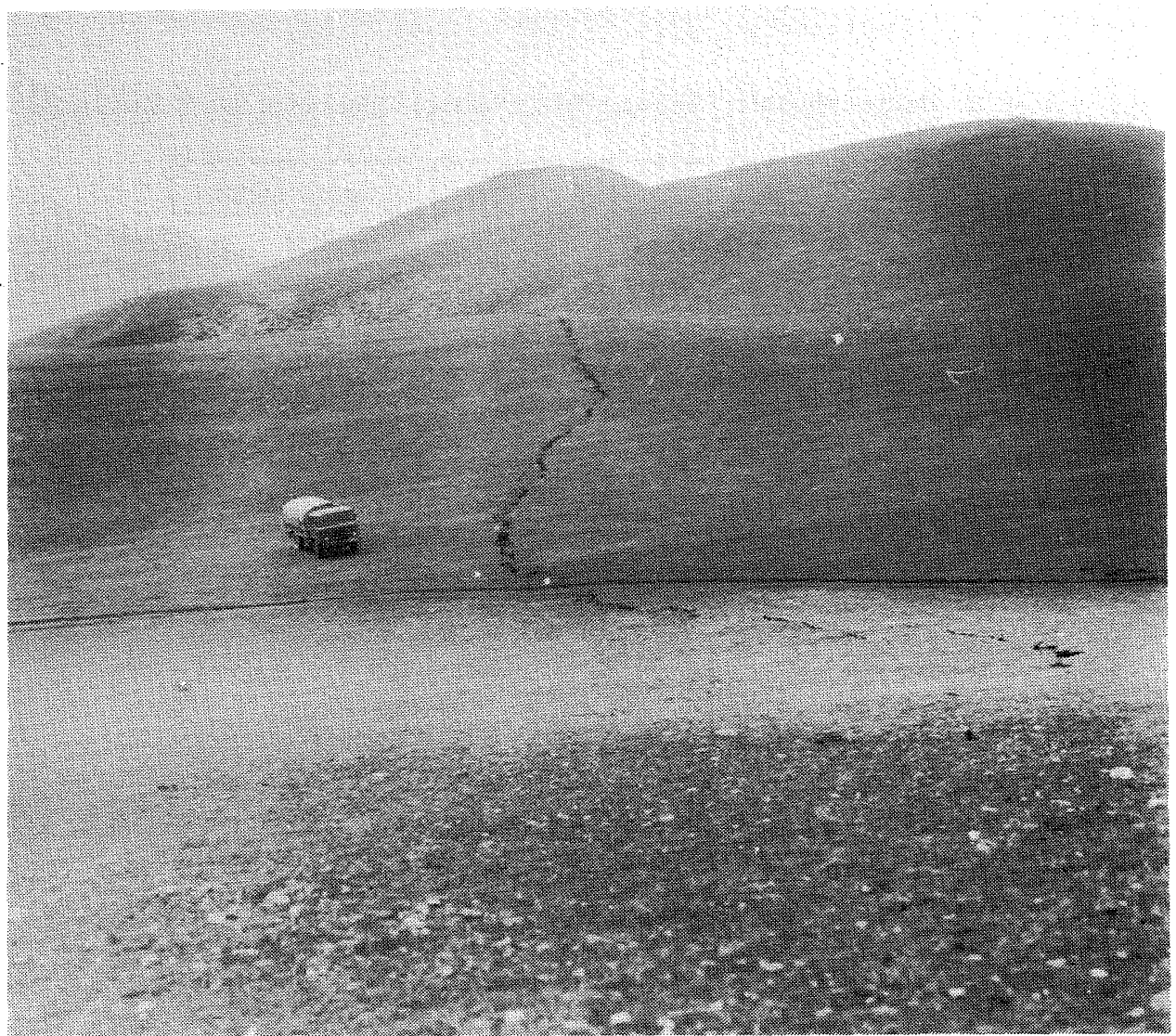

Figure 13 Surface rupture, near its NW end. [A. Karalharion] 


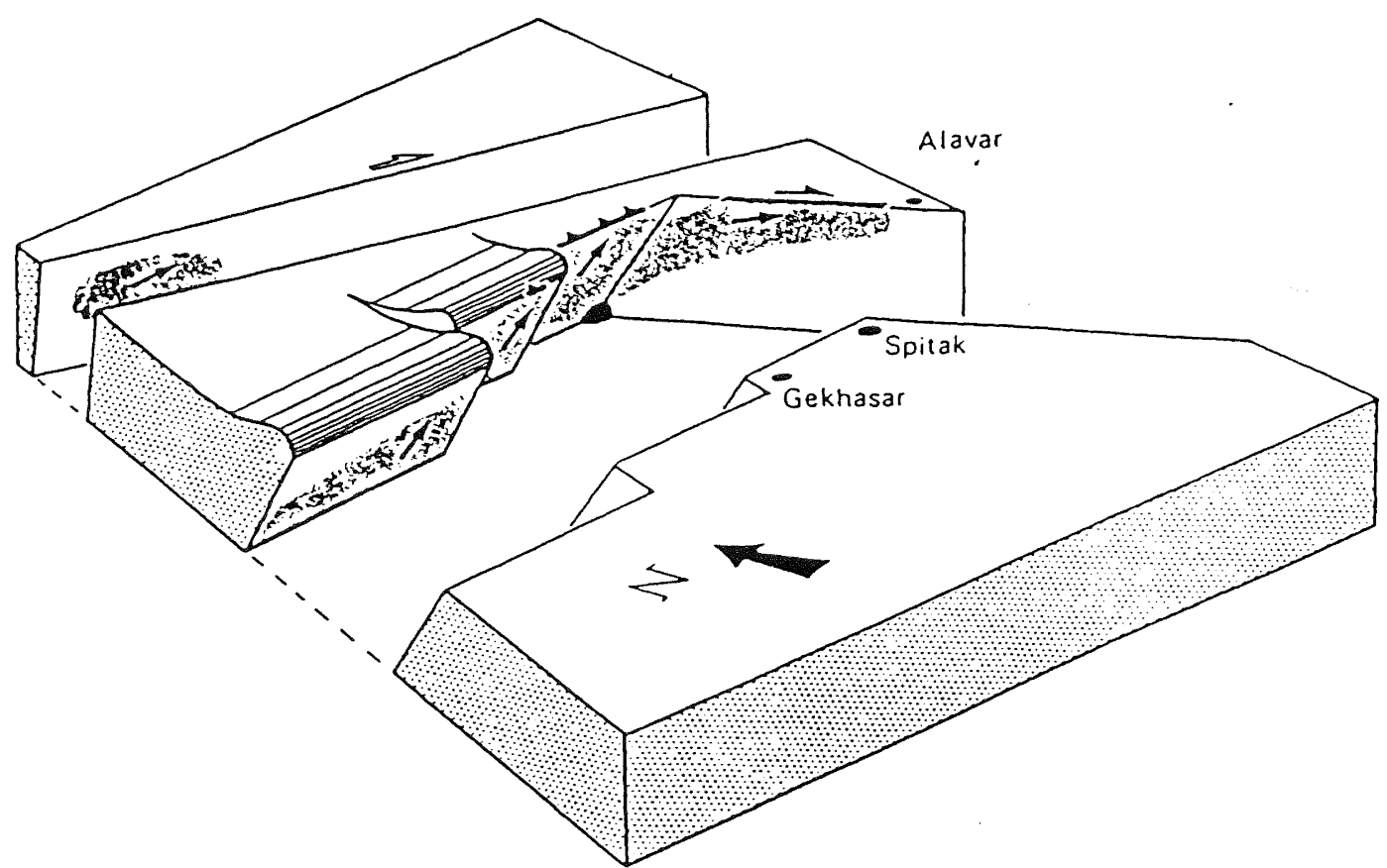

Figure 14 Block diagram of the entire fault zone showing the five branches and the relative motion of the southern block with respect to the northern one. Shaded area corresponds to the ruptured surface as defined by the aftershocks. Amows indicate slip vectors. Thick lines show surface breaks. Black ball at base indicates nucleation point. [Phitip at al, (1992)].

Table II. Design Intensities Compared With Observed Values from Spitak Earthquake

\begin{tabular}{|l|c|c|}
\hline \multicolumn{1}{|c|}{ Locality } & Design Intensity & Observed Intensity \\
\hline Spitak & 7 & $9-10^{-}$ \\
\hline Leninakan & 8 & $8-9$ \\
\hline Kirovakan & 7 & 8 \\
\hline
\end{tabular}

Table III. Strong Motion Data from the Gukasyan records

\begin{tabular}{||c|c|c|c|c|c|}
\hline & $\begin{array}{c}\text { Duration } \\
\text { of } \\
\text { Record }\end{array}$ & $\begin{array}{c}\text { Strong } \\
\text { Motion } \\
\text { Duration } \\
(>5 \% \mathrm{~g})\end{array}$ & $\begin{array}{c}\text { Strong } \\
\text { Motion } \\
\text { Duration } \\
(>10 \% \mathrm{~g})\end{array}$ & $\begin{array}{c}\text { Pulses } \\
(>10 \% \mathrm{~g})\end{array}$ & $\begin{array}{c}\text { Pulses } \\
(>15 \% \mathrm{~g})\end{array}$ \\
\hline Main Shock & $20 \mathrm{sec}$ & $6.9 \mathrm{sec}$ & $2.9 \mathrm{sec}$ & 13 & 8 \\
\hline Aftershock & $16 \mathrm{sec}$ & $2.6 \mathrm{sec}$ & $0.8 \mathrm{sec}$ & 3 & 1 \\
\hline Cumulation & $36 \mathrm{sec}$ & $9.7 \mathrm{sec}$ & $3.7 \mathrm{sec}$ & 16 & 9 \\
\hline
\end{tabular}

From Pomonis, ibid. 
$6^{\text {BORZHOMI }}$

$6-$<smiles>[13CH]=[13CH][13CH3]</smiles>

$\stackrel{\cdot}{5+}^{\text {POSOF }}$

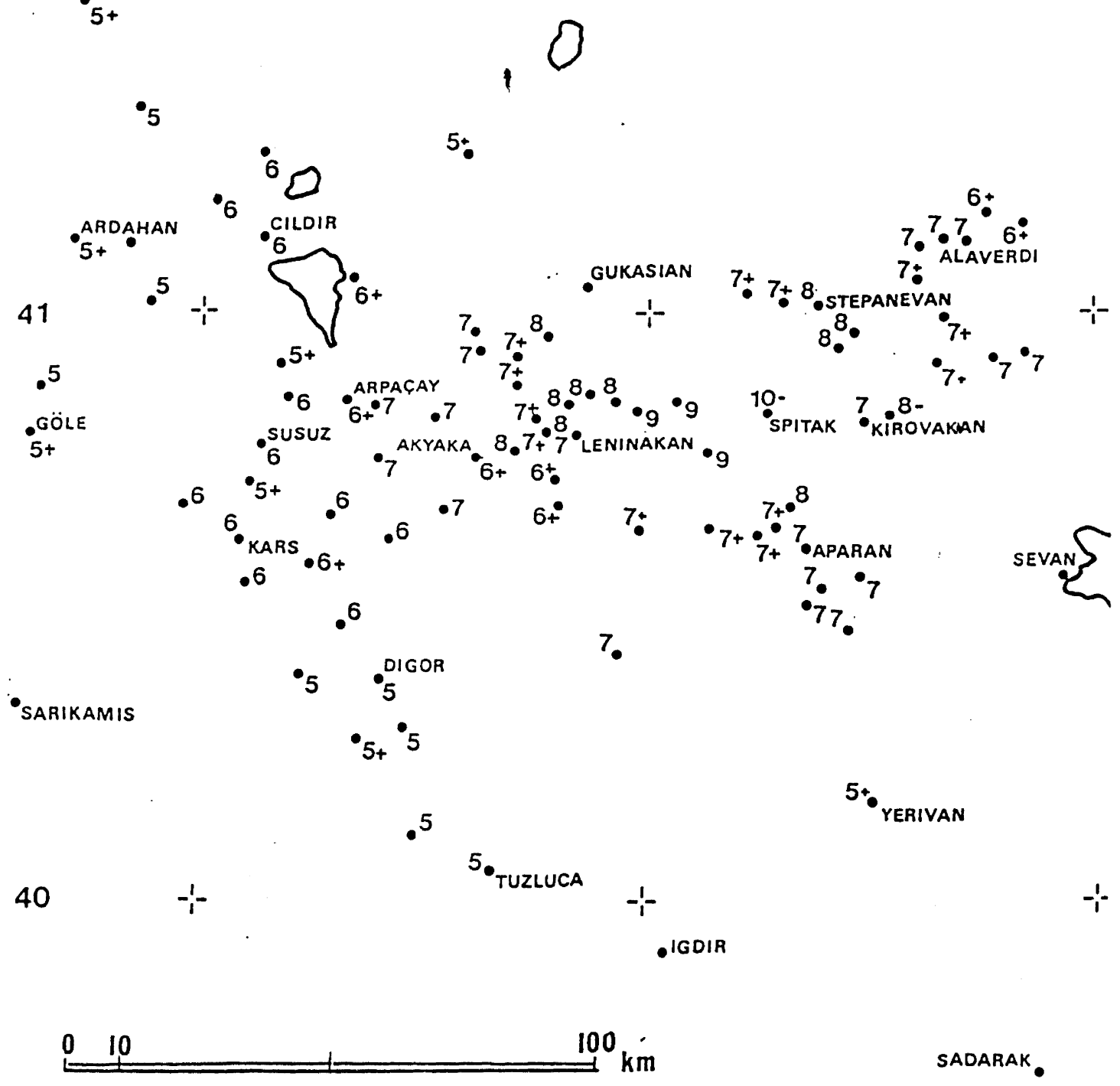

Figure 15 Felt intensities (MSK64) for Armenia, Turkey and Inan. [from Bommer and Ambraseys, (1989)] 

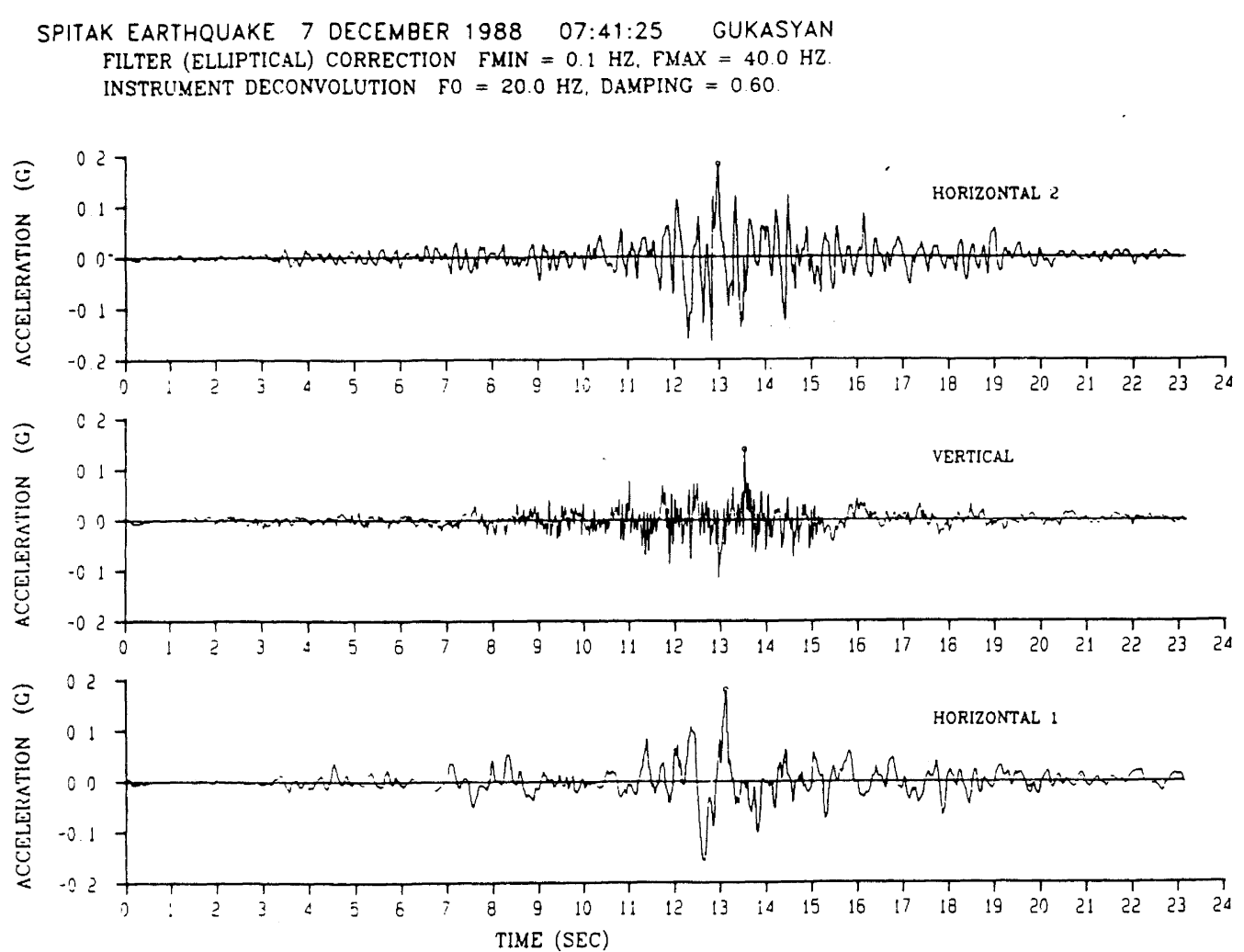

Figure 16 Gukasyan strong motion record. [from Ambraseys and Bommer, (1989)]

Table IV. Acceleration response ordinates recorded in Leninakan by multipendulum seismometers

\begin{tabular}{|c|c|c|c|c|c|c|c|c|c|c|c|c|c|c|c|c|c|}
\hline \multirow{3}{*}{ Site } & \multicolumn{17}{|c|}{$\begin{array}{l}\text { Acceleration Response, } \mathrm{cm} / \mathrm{s}^{2} \\
(\text { Damping }=5 \%)\end{array}$} \\
\hline & \multicolumn{17}{|c|}{ Natural Period, s } \\
\hline & 0.05 & 0.10 & 0.13 & 0.15 & 0.18 & 0.20 & 0.22 & 0.25 & 0.30 & 0.33 & 0.4 & 0.5 & 0.6 & 0.7 & 0.8 & 0.9 & 1.0 \\
\hline $\begin{array}{l}\text { Geophys Inst. yard } \\
\text { Geophys Inst. base- } \\
\text { ment } \\
\text { Hotel Koomayri } \\
24 \text { Spandaryan St }\end{array}$ & $\begin{array}{r}32 \\
0 \\
17 \\
60\end{array}$ & 130 & $\begin{array}{r}165 \\
0\end{array}$ & $\begin{array}{r}150 \\
90 \\
180\end{array}$ & $\begin{array}{r}180 \\
0 \\
105 \\
0 \\
\\
600\end{array}$ & 180 & $\begin{array}{r}145 \\
0\end{array}$ & $\begin{array}{r}600 \\
130 \\
0 \\
750 \\
700\end{array}$ & $\begin{array}{l}500 \\
375\end{array}$ & 470 & $\begin{array}{c}65 \\
0 \\
\\
35 \\
0\end{array}$ & $\begin{array}{c}45 \\
0 \\
\\
\\
72 \\
0\end{array}$ & $\begin{array}{c}30 \\
0 \\
76 \\
0\end{array}$ & $\begin{array}{c}35 \\
0\end{array}$ & $\begin{array}{l}75 \\
50\end{array}$ & $\begin{array}{c}42 \\
0\end{array}$ & 50 \\
\hline
\end{tabular}




\subsection{Site effects}

Variation in earthquake damage at locations such as Spitak, Kirovakan and Leninakan was evident. Damage in Leninakan was much greater than that at Kirovakan although both were about the same distance from the fault rupture. This difference has been attributed by many authors [Aptekman et al., 1989 Borcherdt et al., 1989, Bommer \& Ambraseys, 1989a, 1989b] to amplification by the 300-400 m deep sedimentary basin underlying Leninakan. Evidence for site effects at Leninakan comes from three sources: the variation in the distribution of damage amongst similar building types on different ground conditions, aftershock recordings, and analytical modelling.

The EERI team [Wyllie \& Filson, 1989] report that for stone buildings of 4 storeys or less the damage was similar at Leninakan and Kirovakan. But for taller buildings of the frame-stone type, $62 \%$ collapsed or were demolished at Leninakan whereas only $23 \%$ were similarly affected at Kirovakan. For precast frame buildings, including the common Soviet Type 111 structures (a 9 storey precast frame construction), $95 \%$ were destroyed at Leninakan whereas none were destroyed at Kirovakan. The EERI group estimated fundamental natural periods of about $0.3 \mathrm{~s}, 0.5 \mathrm{~s}$ and $0.6 \mathrm{~s}$ for these three classes of structure respectively. The greater damage to longer-period structures points to amplification of long period components in the sediments underlying Leninakan.

Amplification is confirmed by recordings of aftershocks made by the US team. They found marked amplification with respect to nearby rock sites in the period band of 0.5 to 2.5 seconds at the three sites studied in Leninakan [Borcherdt et al. 1989] (Figure 17).

These observations are consistent with theoretical amplification spectra compiled by Dr Shteinberg's group at the Institute of Physics of Earth, Moscow [Aptekman, et al., 1989] and by the USGS group [Borcherdt et al., 1989]. For further discussion of site effects at Leninakan, the reader is referred to Chapters 3 and 4 of the EERI team's report [Wyllie \& Filson, 1989].

The difference in damage between Leninakan and Kirovakan may also be due to their different locations with respect to the radiation pattern of the seismic energy. Westerway (1989) discusses this as an additional or independent cause of the differences in strength of shaking.

\section{GROUND FAILURE}

\subsection{Landslides}

Slope failures were triggered by the earthquake [A. Karakhanian, pers comm.]. They include rockfalls from cuts, block slides (Figure 18), and earthflows.

Philip et al. [1992] note that landslides were more prevalent to the north west of the fault rupture and that the largest landslides occurred there. They suggest an association with a growing anticline above a blind fault - a rupture that did not propagate up to the ground surface but which did deform the ground above it.

\subsection{Liquefaction}

The general lack of liquefaction associated with the earthquake, in spite of its intensities, could be attributed to the absence of susceptible sediments in the mountainous terrain. However, a fairly definite case of liquefaction in the alluvial sediments of the Pemback Valley, about $8 \mathrm{~km}$ west of Spitak and about $1 \mathrm{~km}$ south east of the village of Nalband, was reported to us by a number of sources. This location is near the surface trace of the fault. The U.S. Reconnaissance team was convinced of the occurrence of liquefaction here by reports from the Armenian geologists and engineers [Wyllie and Filson, 1989]. This case was described to us by Professor A. Karapetian and Dr A. Karakhanian who detailed sand boils $300 \mathrm{~mm}$ high (sand of $\phi 1.3 \mathrm{~mm}$ ), and was also confirmed by Professor Ilyichev who referred to sand volcanos of 1 to $2 \mathrm{~m}$ diameter. Unfortunately, the field was ploughed shortly after the earthquake, to get rid of the ejected sand.

Another possible case of liquefaction, this time on a slope, comes from a report of sand ejection associated with a small mud flow $5.5 \mathrm{~km}$ north of Spitak [A. Karapetian and A. Karakhanian, pers. comm.]. Professor Ilyichev reported a third suspected case of liquefaction on the high terrace near the Spitak railway station.

\section{GROUND DEFORMATION}

Vertical ground deformation of more than $100 \mathrm{~mm}$, with a maximum of $1009 \mathrm{~mm}$, was observed at Spitak by a levelling route of some 7 kilometres across the alignment of the fault ruptures there, levelled before and after the earthquake. Discrete vertical displacement of the ground at the fault ruptures was barely detectable by eye [A. Karakhanian, pers. comm.; Lienberg \& Jaschenko, 1989].

\section{AFTERSHOCKS}

The location of the numerous aftershocks, recorded by the combined instruments of the Soviets, French and U.S., are shown in Figure 19. The aftershocks generally coincide with the rupture surface estimated from both the teleseismic model and the observed surface faulting.

\section{ENGINEERED STRUCTURES}

\subsection{Bridge Abutments and Retaining walls}

Apart from bridge abutments, no mass concrete retaining walls were identified in the epicentral area. A number of low cut-stone walls were seen at Spitak and most of these were undamaged or had at most one or two capping stones missing. Figures 20 and 21 show typical examples. The only wall that we saw to have suffered serious damage was found at the northern end of the precast concrete highway bridge under construction over the Pemback River at the time of the earthquake. Here, an old masonry wall, shown in Figure 22, about $2 \mathrm{~m}$ high, about $500 \mathrm{~mm}$ deep at the top and about 50 $\mathrm{m}$ long, retaining a horizontal backfill, had moved out of plumb by about 5 degrees over most of its length. At its highest point, a length of about $12 \mathrm{~m}$ had collapsed. 

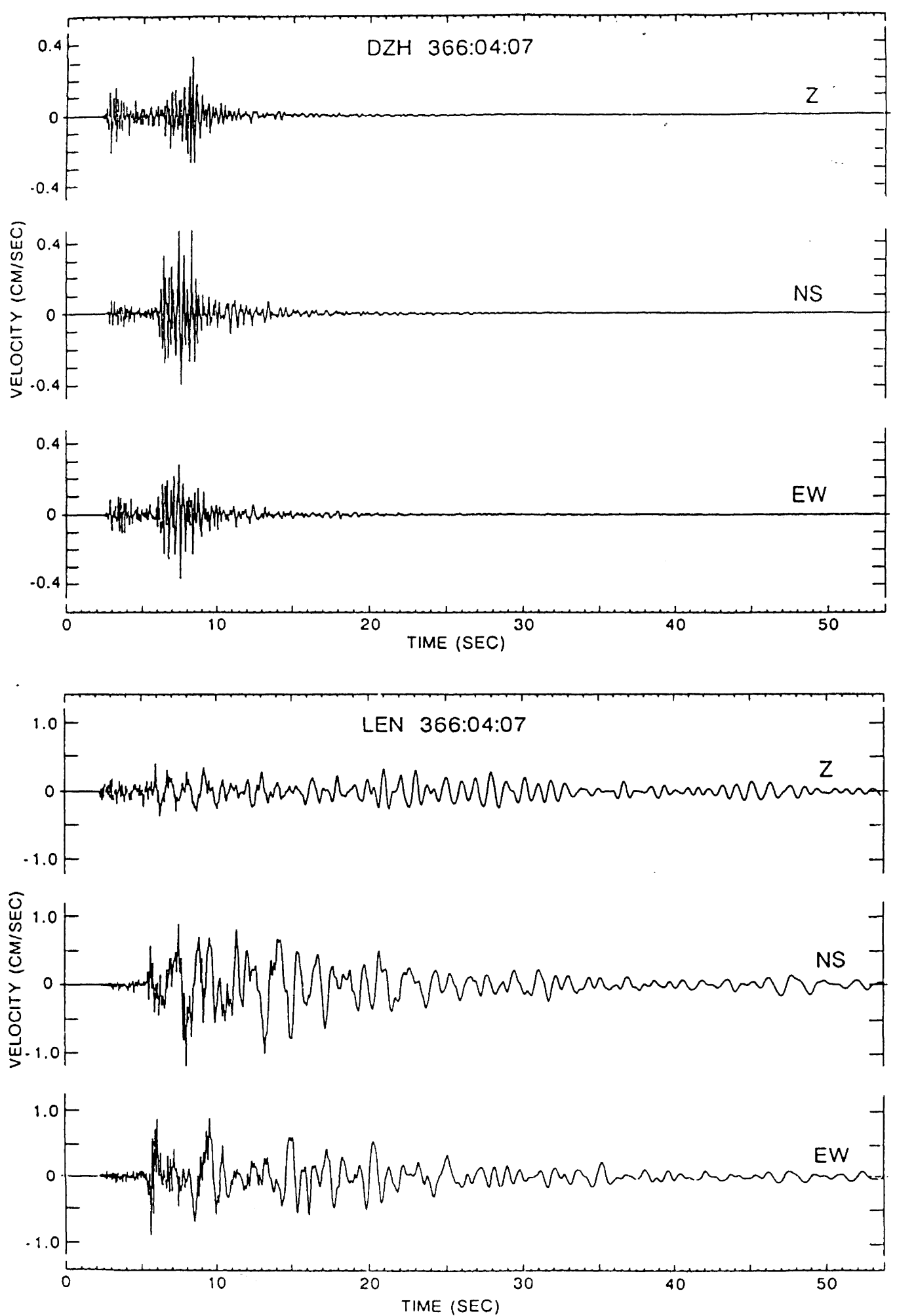

Figure 17 Site response differences between a hard rock site (DZH) and Leninakan from an aftershock of 31 December 1988 [from Wyllie and Filsom, (1989)] 
The French team noted that a similar wall on the bank of the Pemback River at Spitak collapsed over a length of about $100 \mathrm{~m}$. That was the only major wall failure recorded by that group [AFPS, 1989].

Generally, bridge abutments behaved well, and little damage was visible at the time of our visit. The most notable abutment failure occurred on a railway overpass at Spitak, where the failure of a $6 \mathrm{~m}$ high masonry abutment caused collapse of the superstructure [Wyllie and Filson, 1989]. Restoration of the bridge took 19 days. A railway bridge at Nalband was also damaged by abutment failure [AFPS, 1989]. Here, the roughly $8 \mathrm{~m}$ high south east abutment rotated outwards by about $400 \mathrm{~mm}$ at the top, and at the north abutment a gravity masonry wingwall of about the same height failed.

\subsection{Foundations}

We learnt of no foundation failures during our visit to Armenia, and indeed we received authoritative reports on the absence of foundation problems. The French team note that they found only one case and that was of the pulling out of a small foundation in a factory at Spitak [AFPS, 1989, p. 20 and photo 3-1]. Professor Ilyichev confirmed that there were no known cases of foundation failure, apart from the one case of lifting. He had investigated several cases of suspected foundation failure, and in each case the tilting of the building was caused by structural, not foundation, failure.

During our visit we observed a three storey masonry building in the old central section of Leninakan, one block from the Central Square, where pad foundations were being enlarged and tied together with ground beams (Figures 23 and 24). Excavation was also observed around the pad footings of a low rise steel-framed industrial building on the outskirts of Leninakan.

\subsection{Bridges}

A major highway bridge across the Pambak River (Figures 25 and 26) was under construction at Spitak at the time of the earthquake. It was a some $420 \mathrm{~m}$ long, high level bridge, crossing both the river and its shingle flood plain.

The bridge was designed to have 15 spans of $28 \mathrm{~m}$. The piers consisted of twin bored cylinders continued up to pier cap level with precast segmental cylinders. They were founded in the alluvial gravels, some above and some below the water table. The pier cap was also precast.

The superstructure was to be built of prestressed concrete $T$ beams. At the time of the earthquake all of the pier shafts were constructed and some pier caps and beams had been erected in place but not fastened.

As a result of the earthquake, fault displacement offset the pier alignment at about pier 5. Some pier caps tilted on top of the shafts and some beams fell over, both in place and in stacks on the ground (Figures 26 and 27). Some of the pier shafts tilted slightly in the ground (Figures 26 and 27). The damage can be attributed to the effects of soft alluvial soils overlying the rock, in addition to the effects of displacement of the fault running through the site.

The authorities have decided to abandon the bridge although it is probably repairable at small extra cost. The other surprise was that the existing low level bridge at the site was apparently undamaged. It had high gravity retaining abutments and poor seismic detailing but it was founded directly on rock (Figure 28 ).

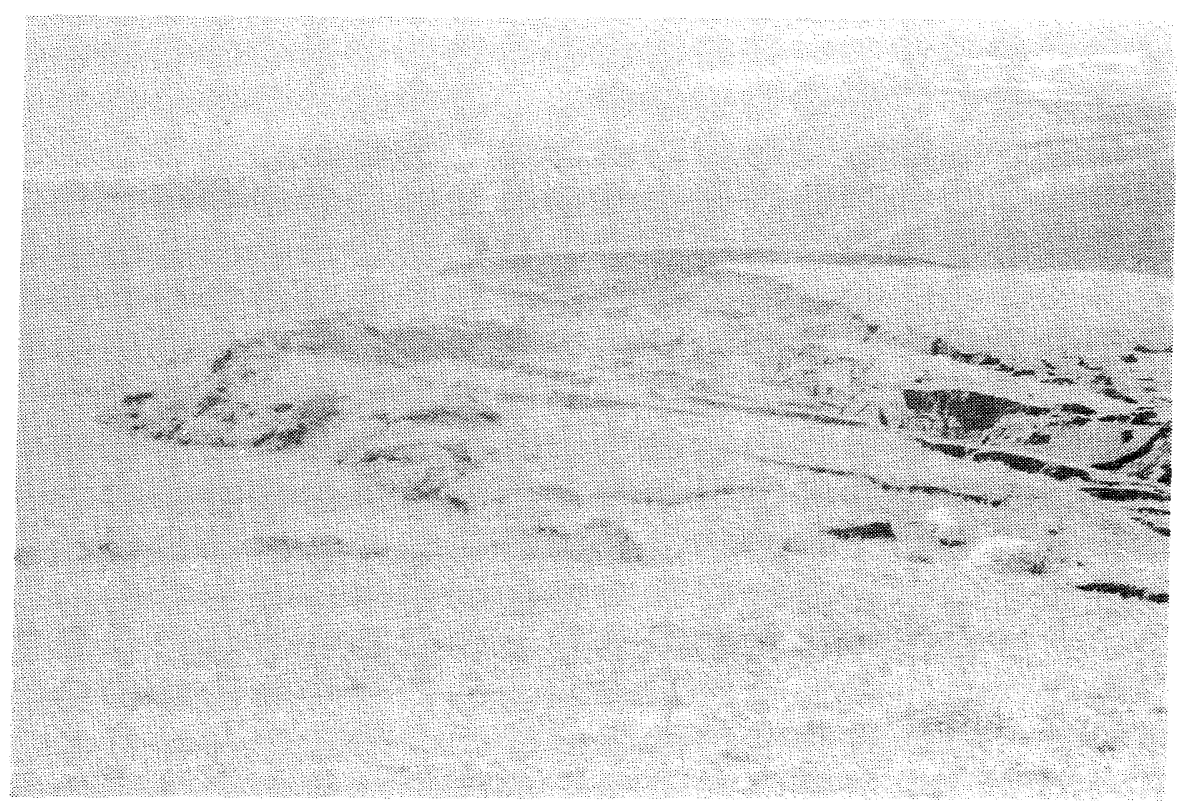

Figure 18 Landslide near NW end of fault nupture. [A. Karakhanian] 

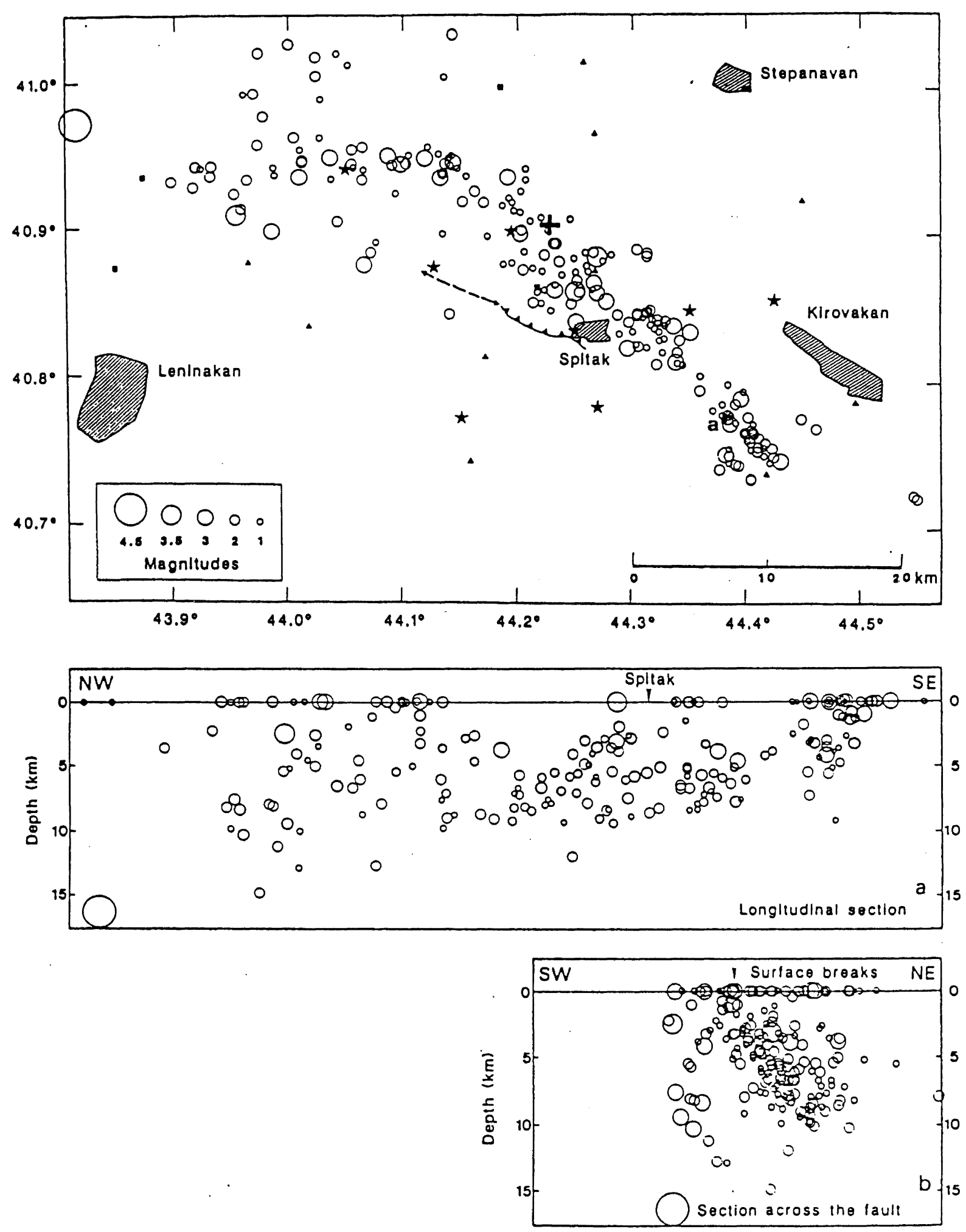

Figure 19 Space distribution of aftershocks from 22 December 88 to 1 Jarulary 89. [from Cistemas at al] 


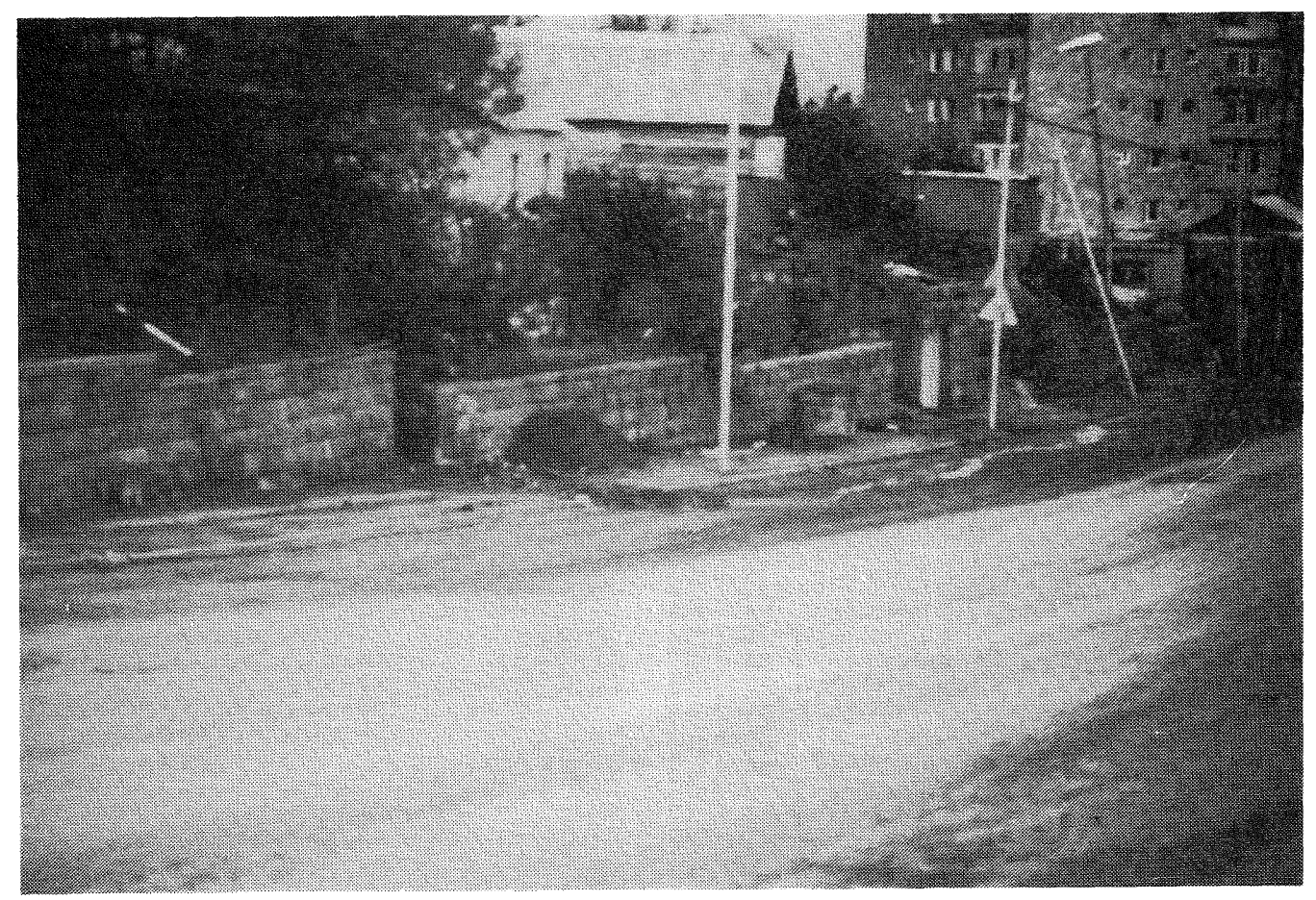

Figure 20 Stone wall, Spitak.

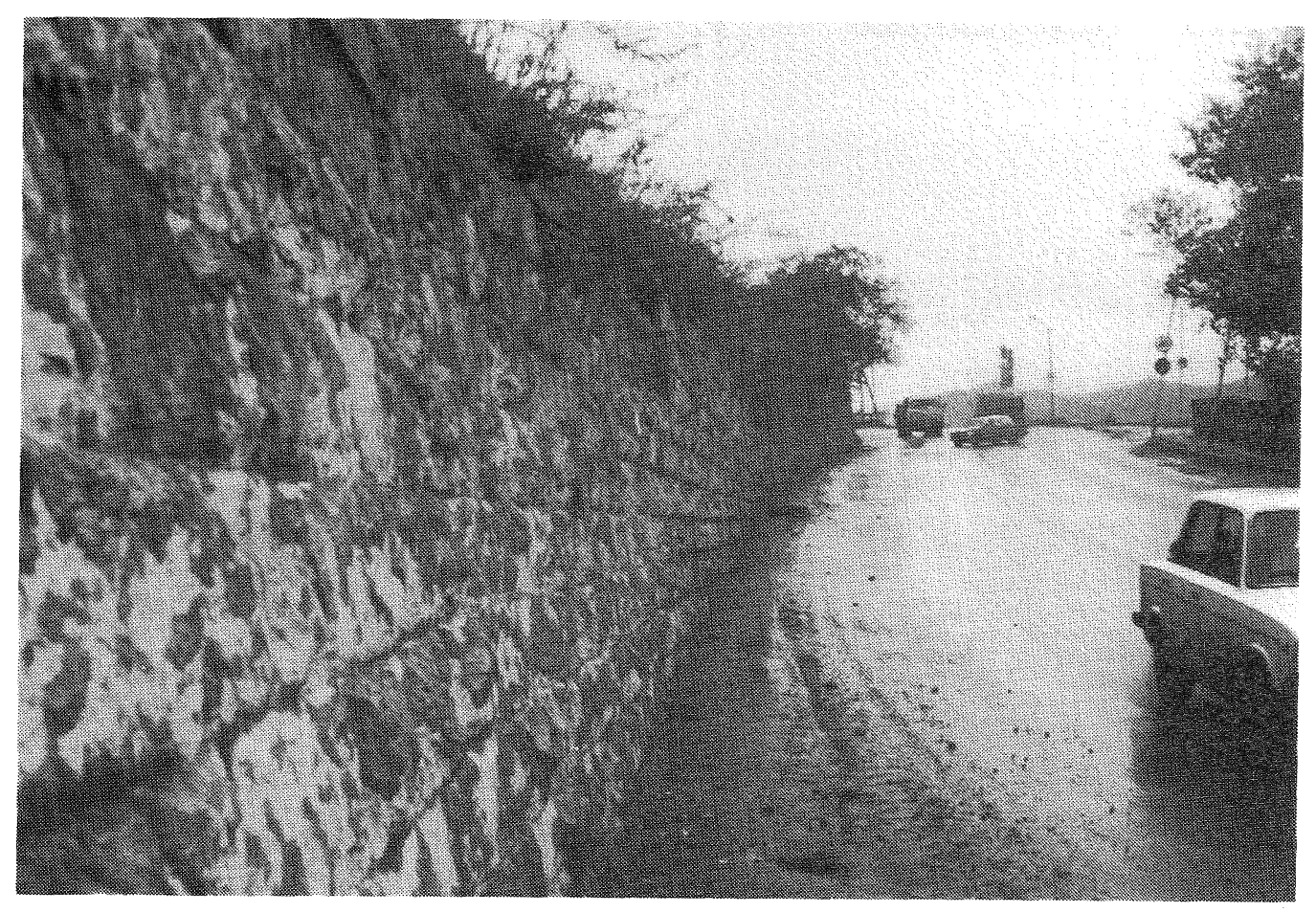

Figure 21 Cut stone wall, Spitak. 


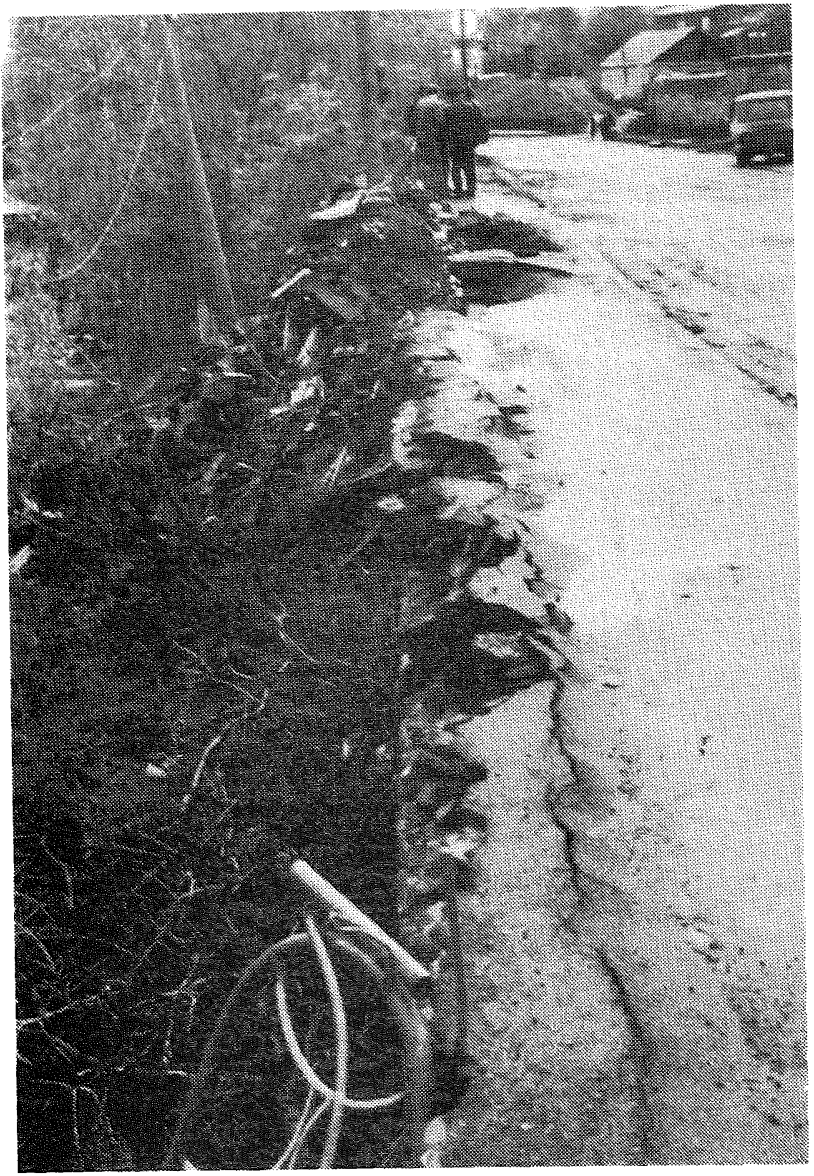

Figure 22 Collapsed wall, Spitak.

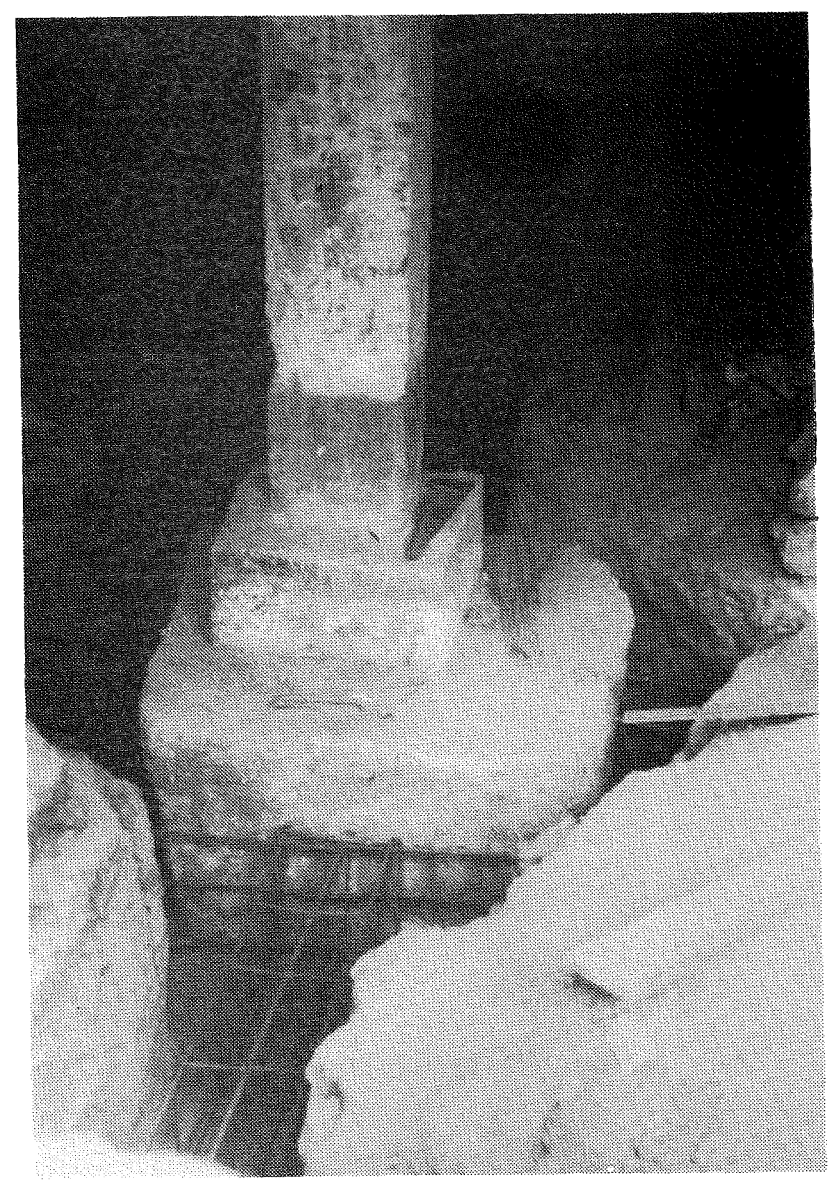

Figure 23 Spread footings being extended and tied together in old quarter of Leninakan.

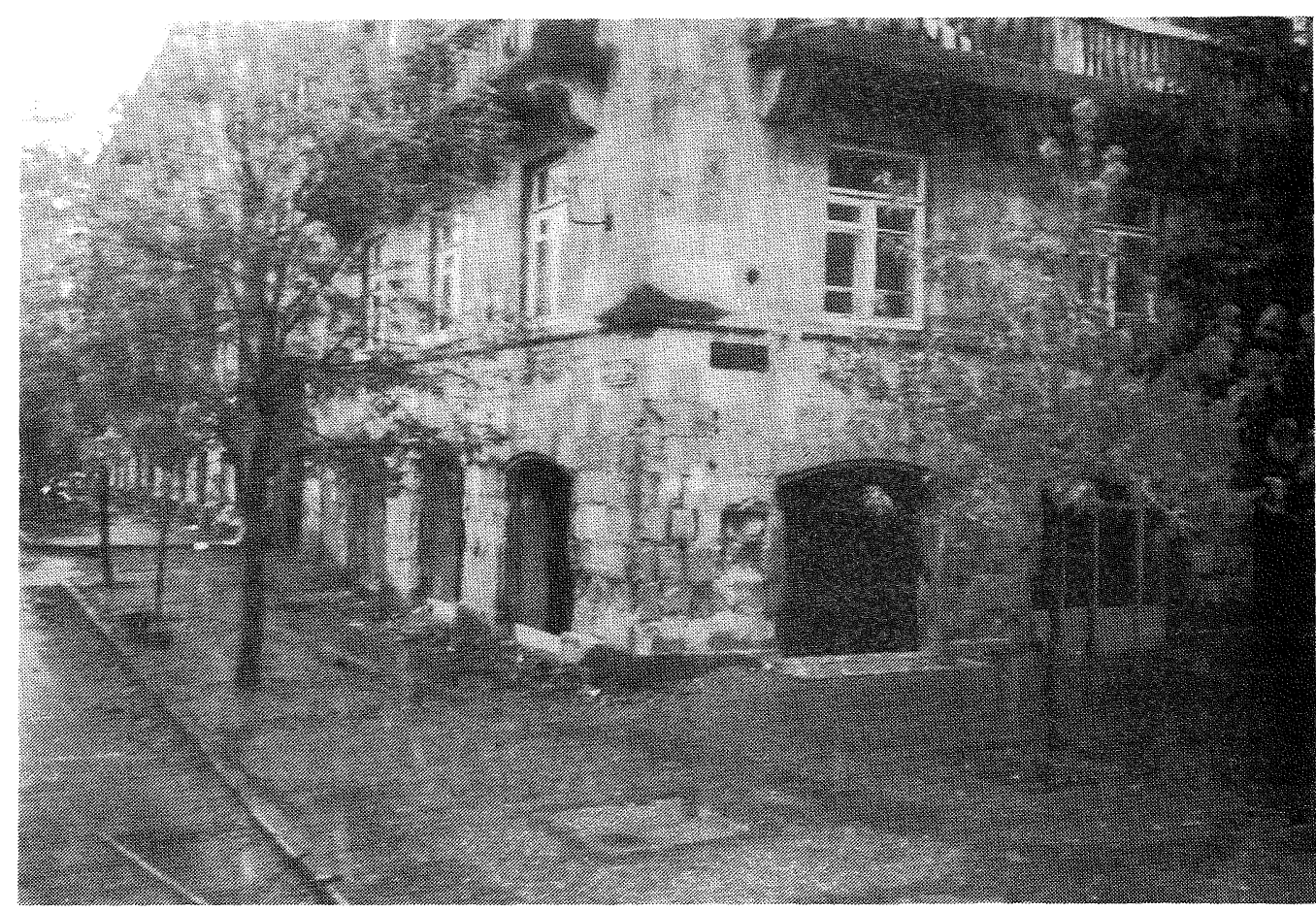

Figure 24 Building in which spread footings were being extended. 


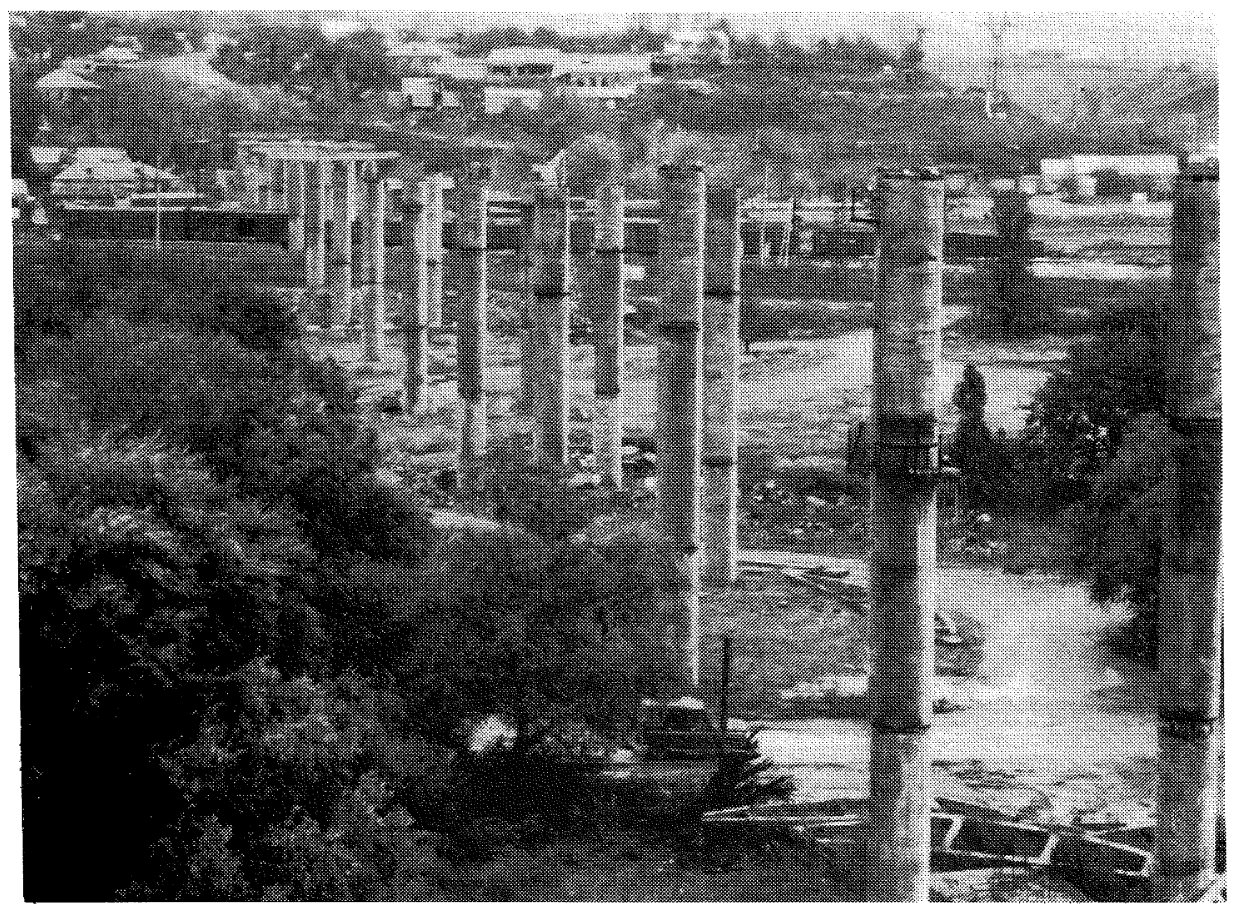

Figure 25 Precast, prestressed concrete highway bridge, under construction at Spitak at time of earthquake.

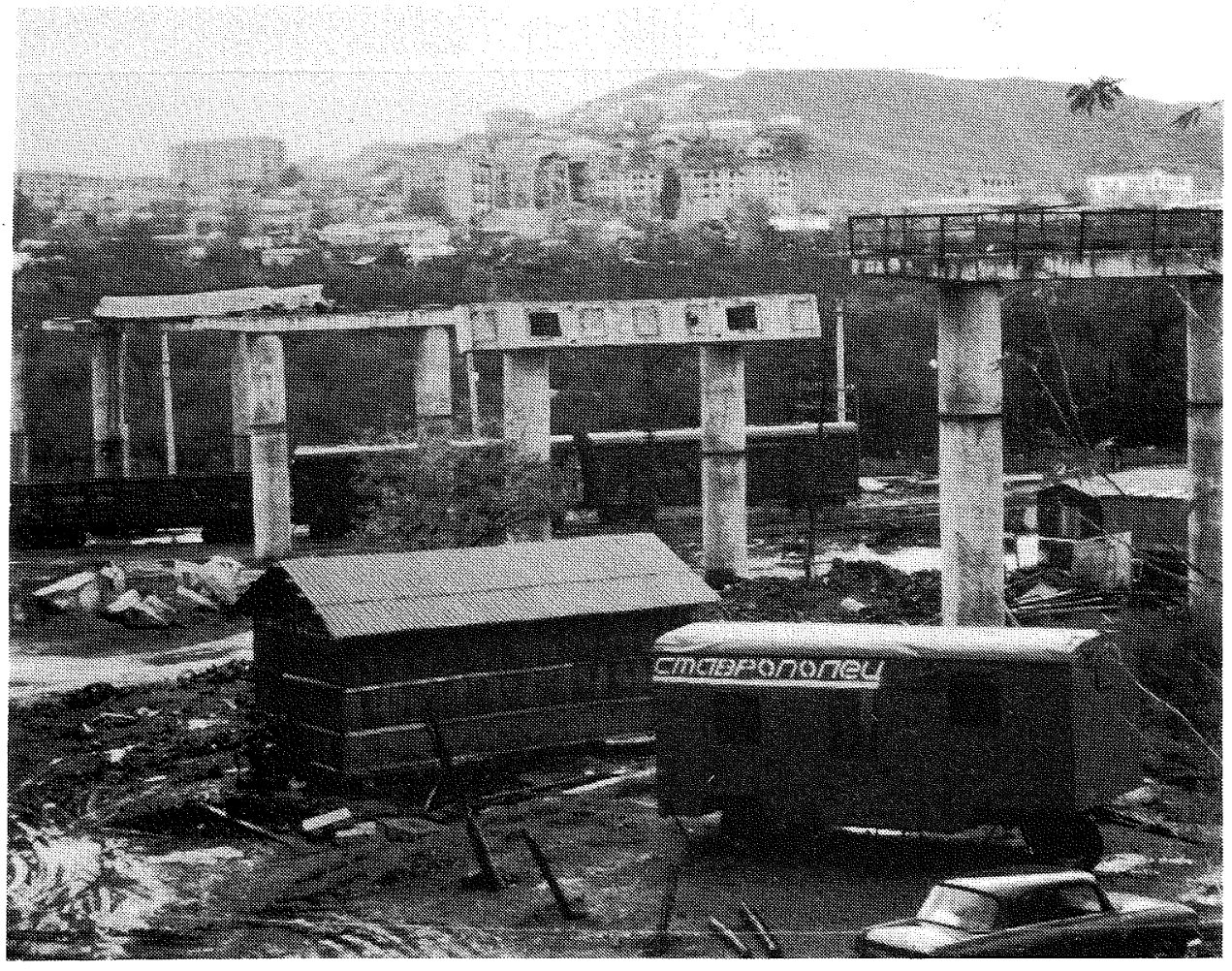

Figure 26 View of Spitak bridge, looking in the other direction. 


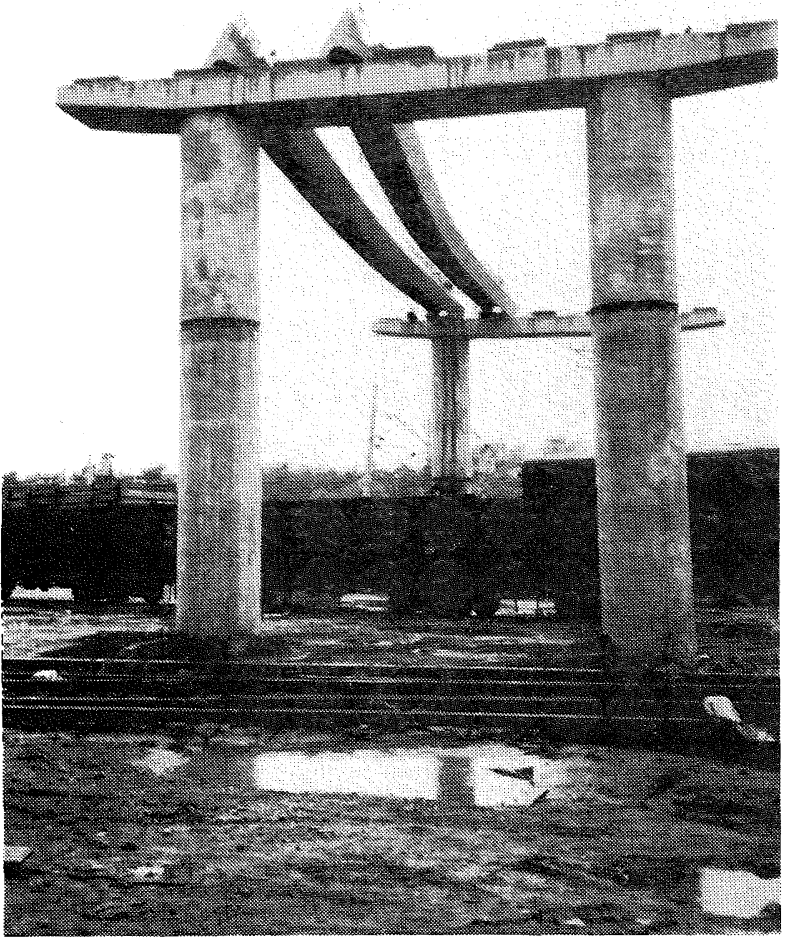

Figure 27
Toppled precast beams, Spitak highway bridge.

\subsection{Buildings}

When our team visited the area, much of the damage had been cleared away but there were many severely damaged buildings left standing (Figures 29 and 30). Previous reconnaissance teams have recorded the damaged buildings well [e.g. Wyllie \& Filson, 1989].

We noted that the high rise apartment buildings performed particularly badly and contributed significantly to the high loss of life. We noted three predominant types of high rise building: precast panels, precast frames and lift slab.

Most of the buildings that failed were of the Soviet Building Type 111 series, of 9 storey precast frame construction. Seventy eight had been built in Leninakan and only 6 survived the earthquake, but these, too, were damaged beyond repair. We examined the last one standing before it was demolished (Figures 31, 32 and 33).

In Spitak the team also examined some frame buildings that had been under construction at the time of the earthquake and had not yet been demolished. They clearly indicated very low construction standards which exacerbated suspect joint details (Figures 34, 35, 36 and 37).

The precast panel buildings performed better than the frame buildings but once again construction standards aggravated poor joint details. No doubt the grinding movement provided some ductility and reduced the building response. None the less, the panel buildings are very brittle and would collapse completely soon after first yield. Those that failed started to fail at the bottom first.

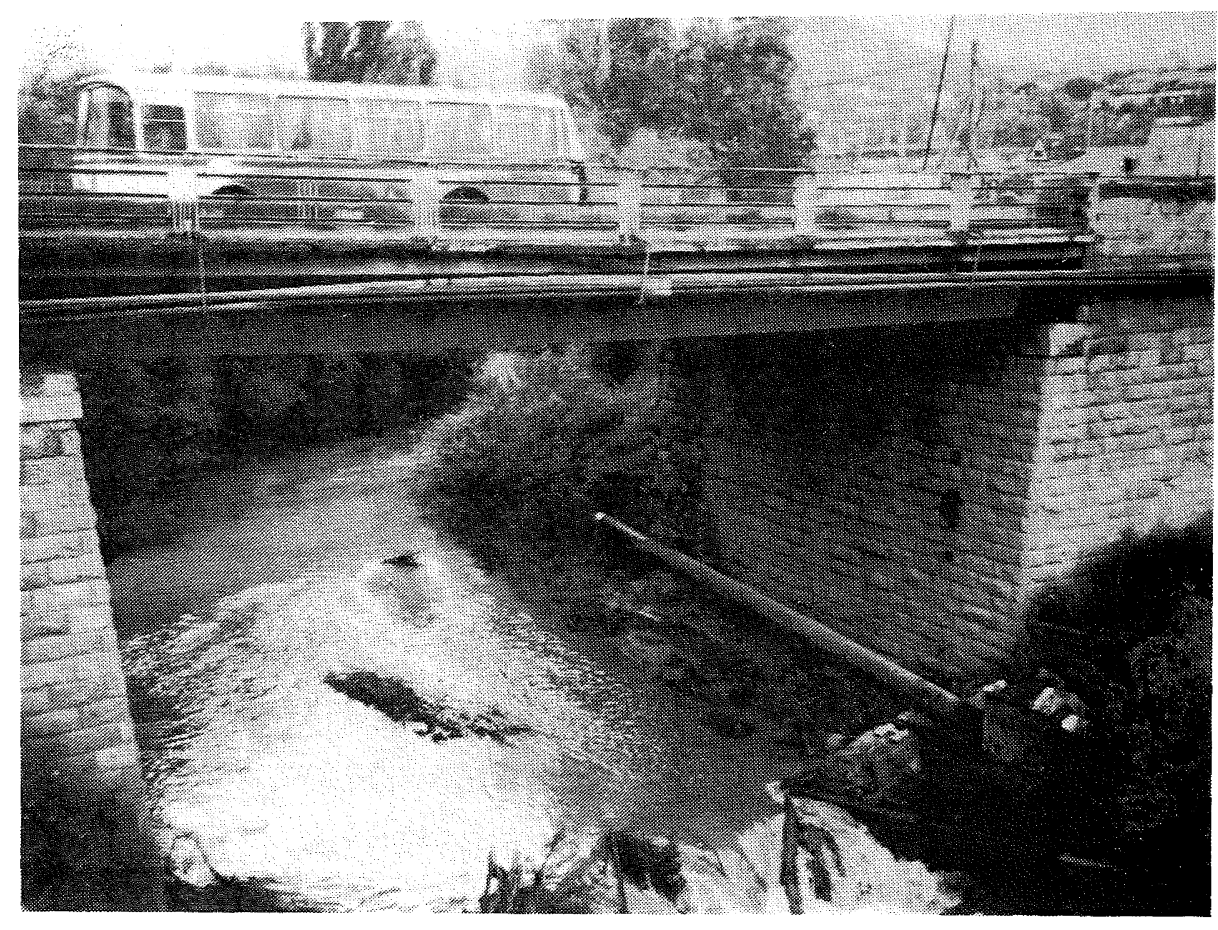

Figure 28 Old bridge acrass Pembak River at Spitak, undamaged. 


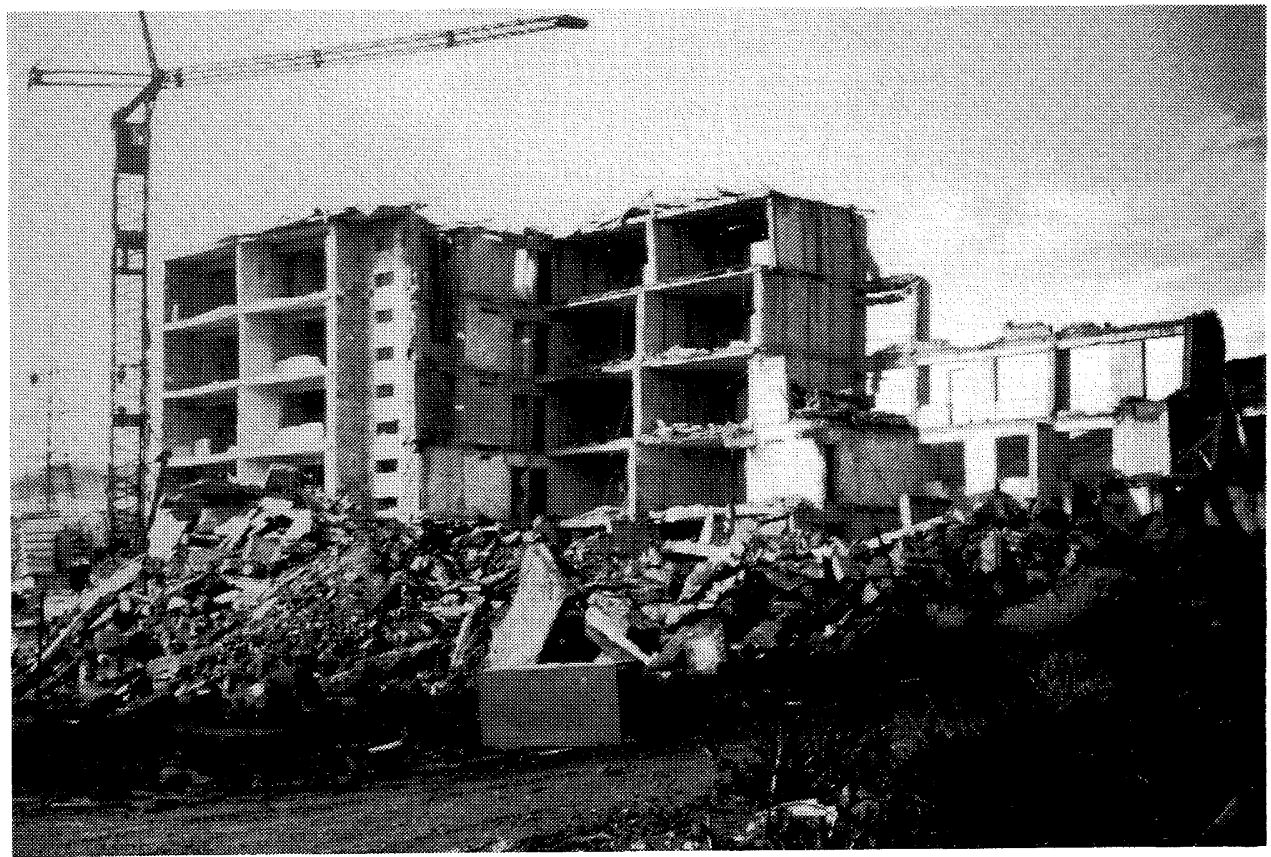

Figure 29 Damaged reinforced concrete building, Spitak.

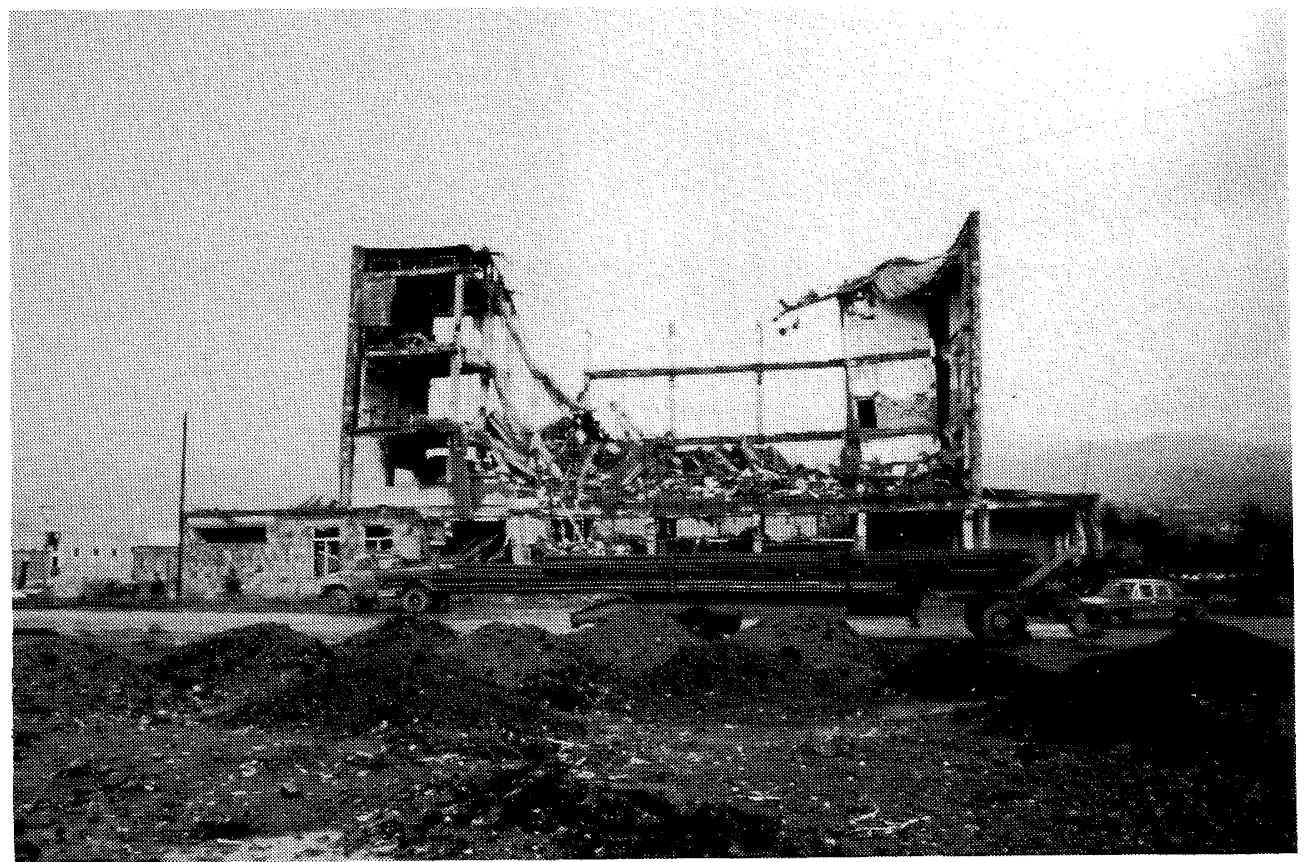

Figure 30 The main telephone exchange in Spitak after the earthquake. 
There were two high rise lift slab buildings in Leninakan and they both failed in the earthquake. One of 6 storeys stayed up but lost $30 \mathrm{~cm}$ in height because of crushing of the core at the first floor level. The second building, of 10 storeys collapsed completely. Many similar buildings could be seen under construction in Yerevan (Figure 38).

Masonry buildings up to 2 storeys performed reasonably well in Leninakan and Spitak. An exception was the 19th century cathedral in Leninakan (Figure 39). We were told that it will be restored faithfully stone by stone to the original design.

There were masonry buildings above 2 storeys and up to 5 storeys in Spitak and they failed top down.

The authorities have decided rightly or wrongly that precast elements will not be used again. New buildings in Leninakan are being constructed as cast in situ rigid shear wall monoliths.

All of the building types discussed above are represented in large numbers in Yerevan. The cost of retrofitting these is beyond the capacity of the Armenian economy at present, but they must represent a grave risk.

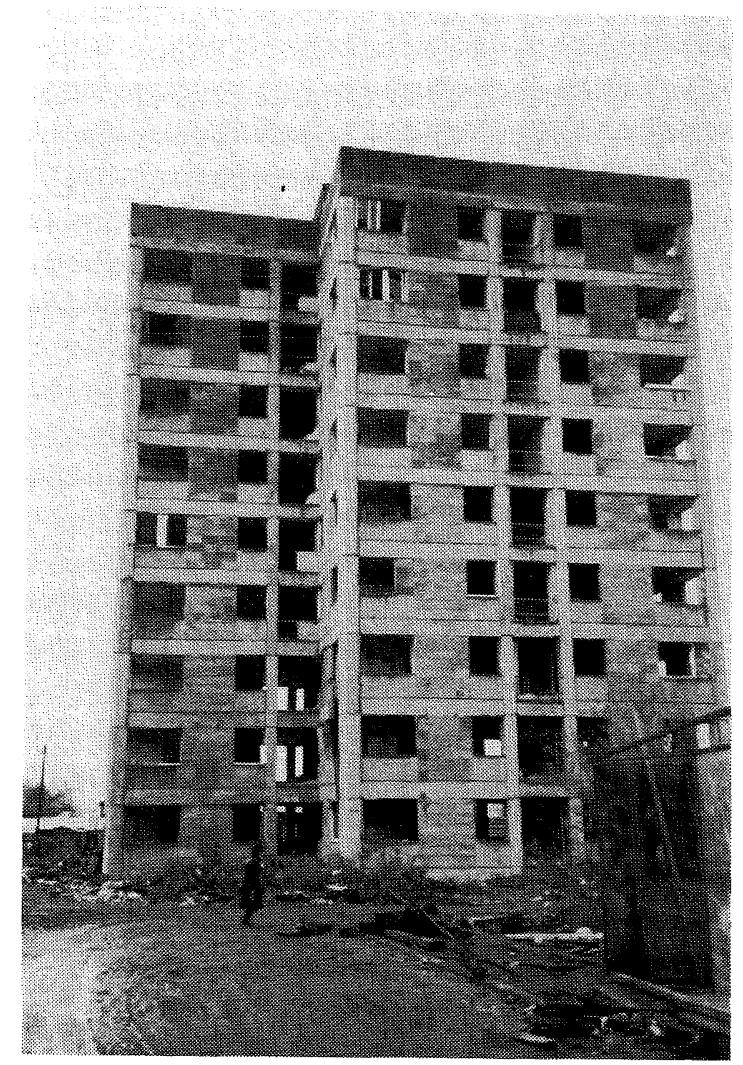

Figure $31 \quad$ Type 111 building, heavily damaged but still standing, at Leninakan.

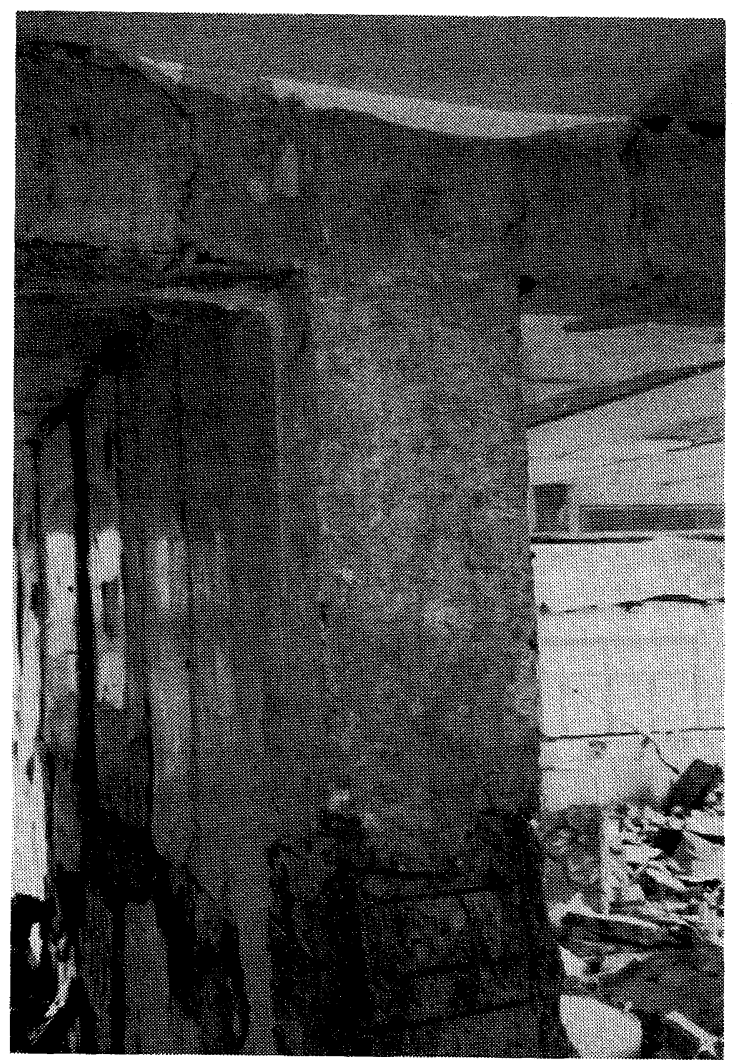

Figure 33 Details of the Type 111 building.
Figure 32 Details of the Type 111 building.

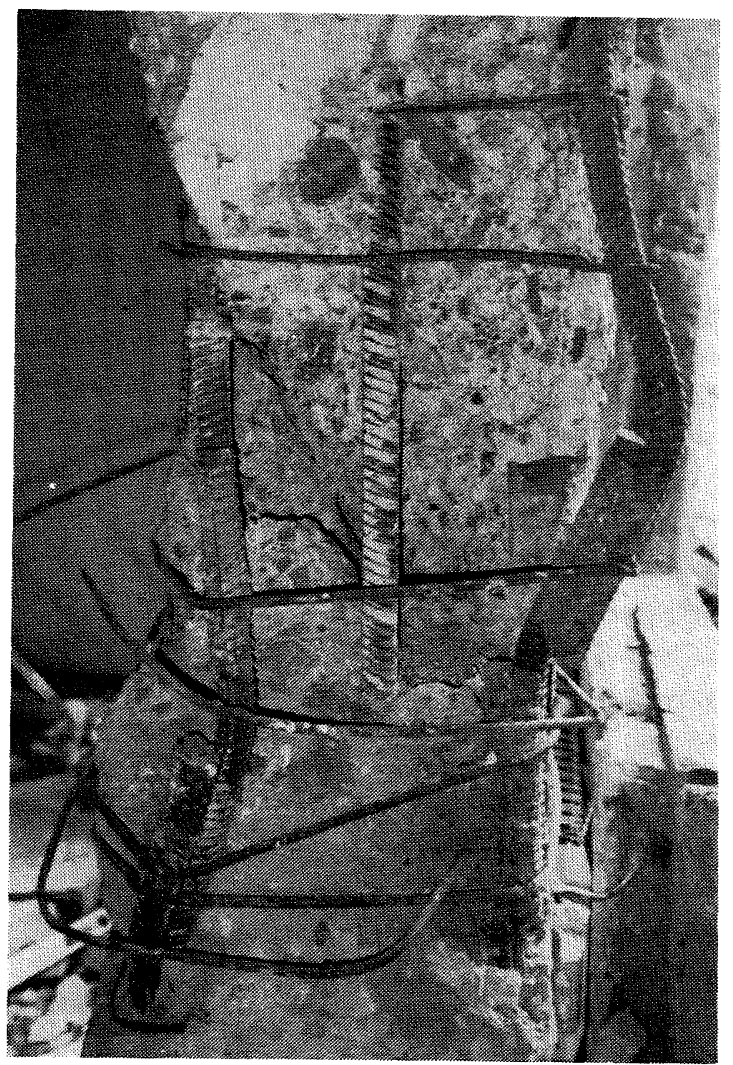




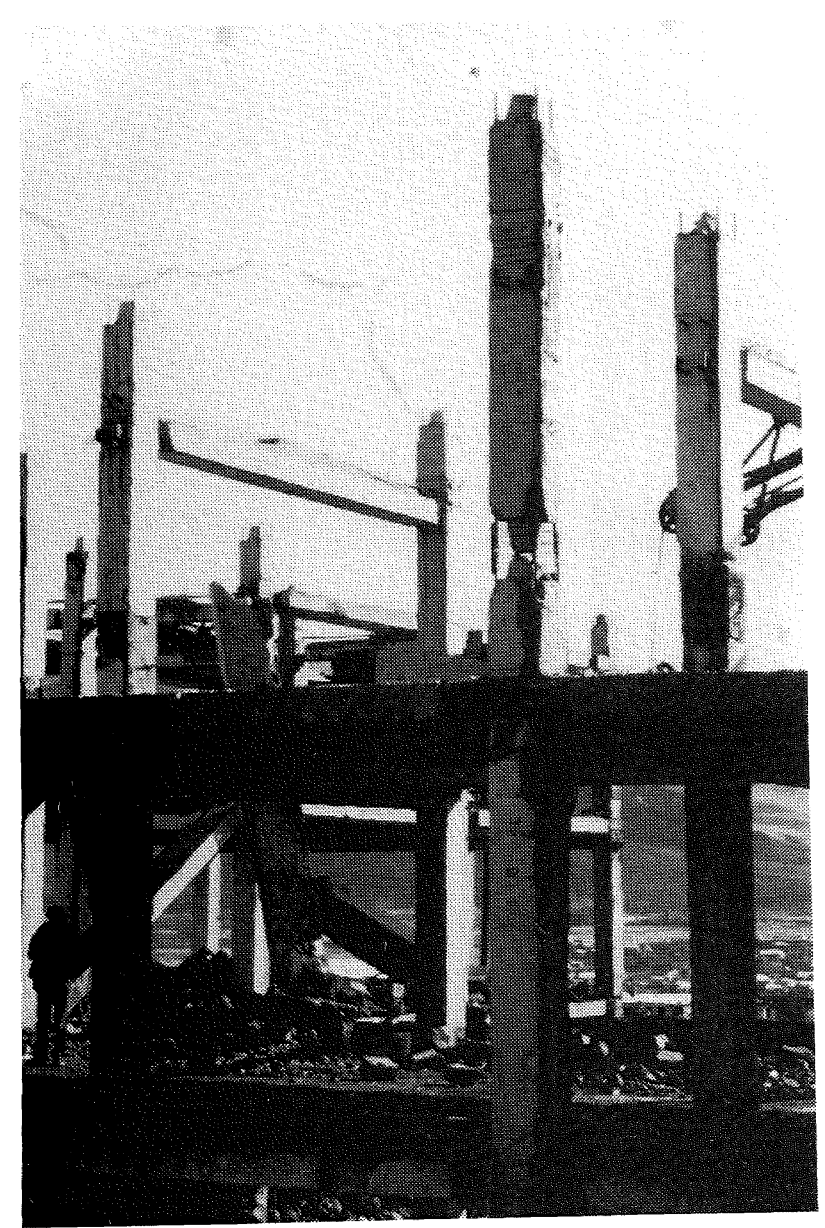

Figure 34
Precast concrete frame building, under construction at Spitak.

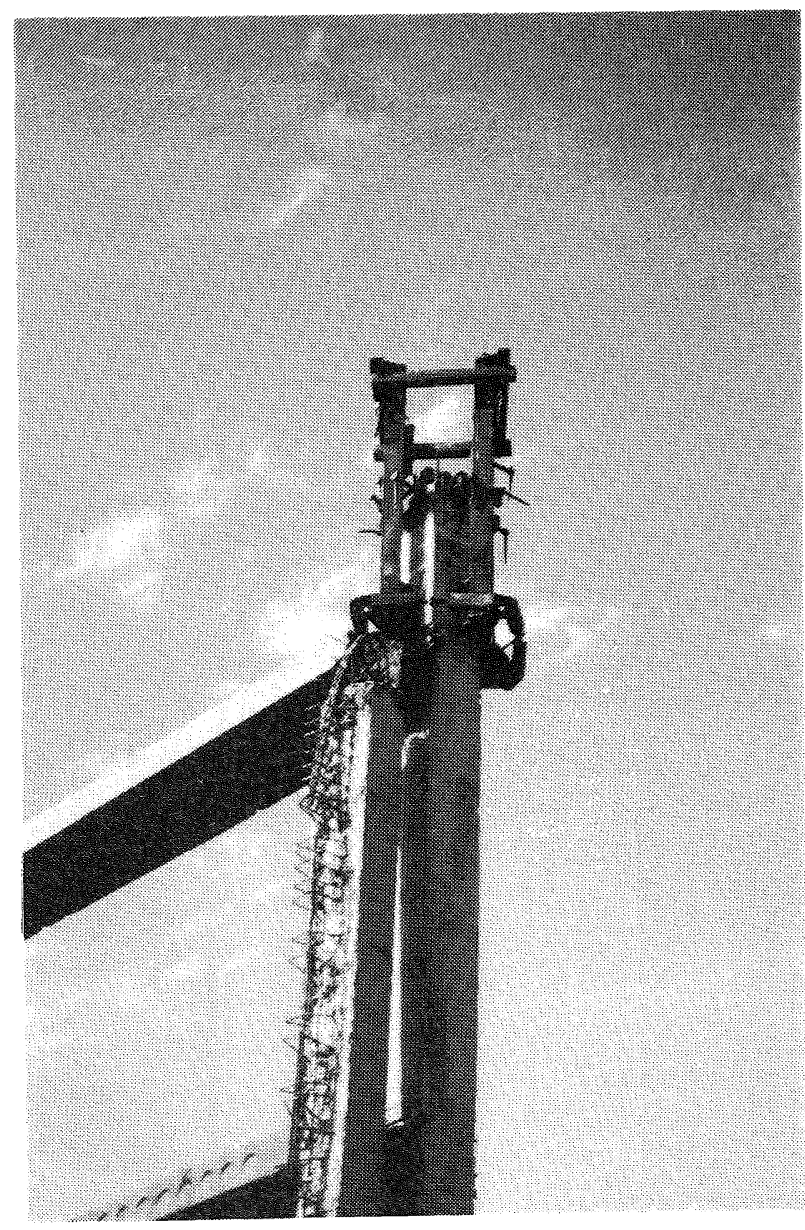

Figure 35

Precast concrete frame building, under construction at Spitak.

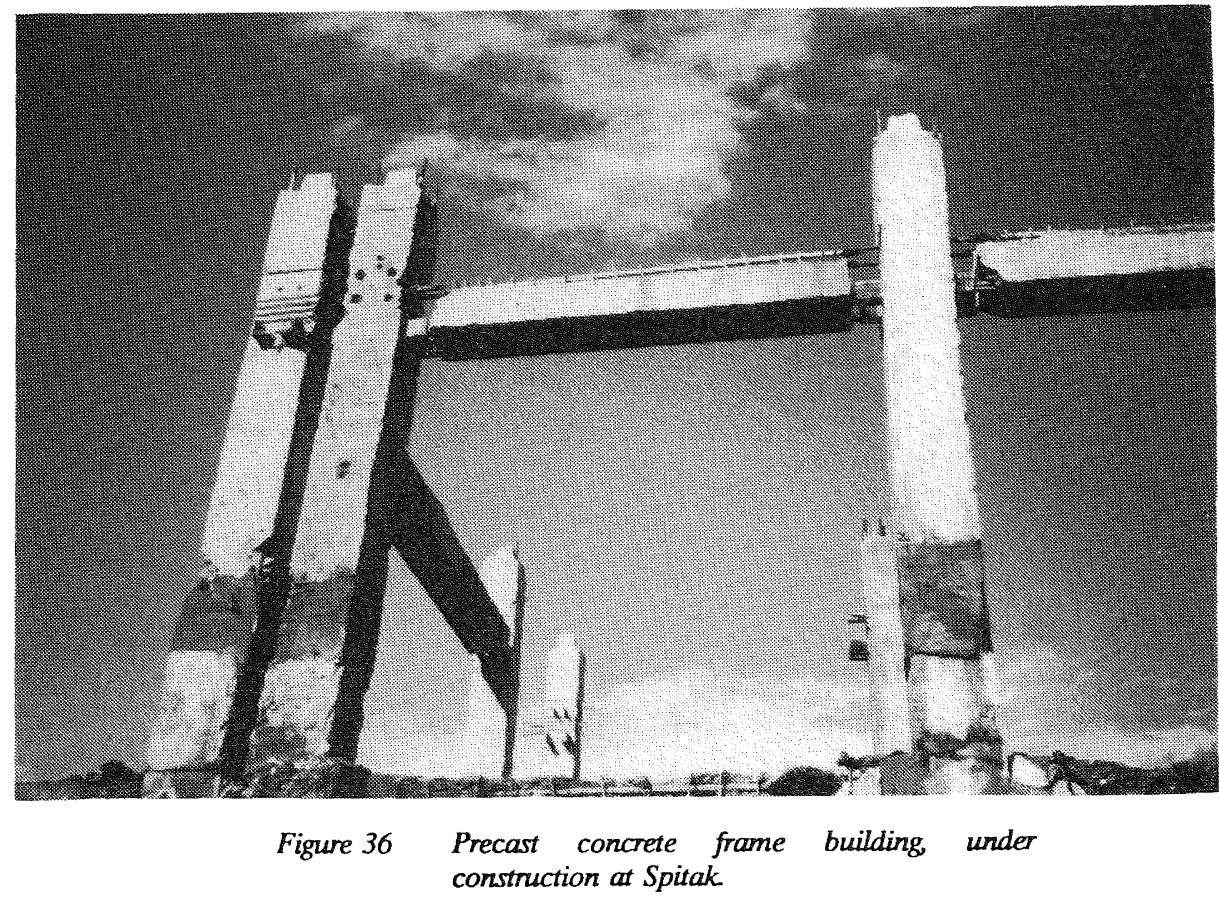




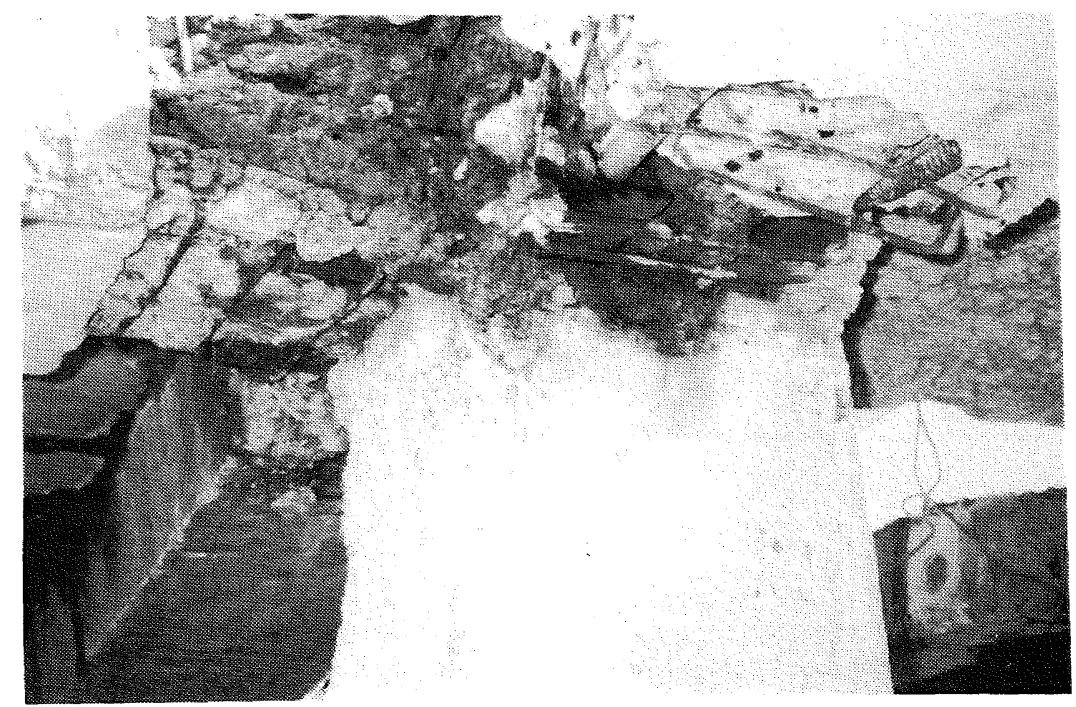

Figure 37 Precast concrete frame building, under construction at Spitak.

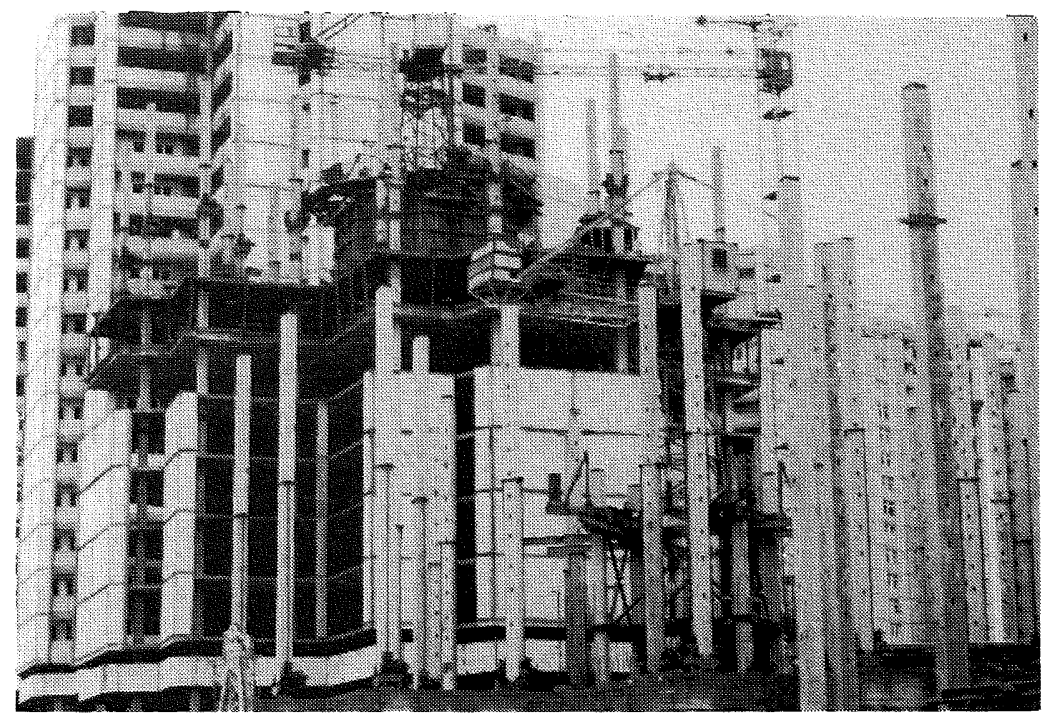

Figure 38 Lift slab building under construction on the northern outskirts of Yesevan. Similar structures collapsed in Leninakan.

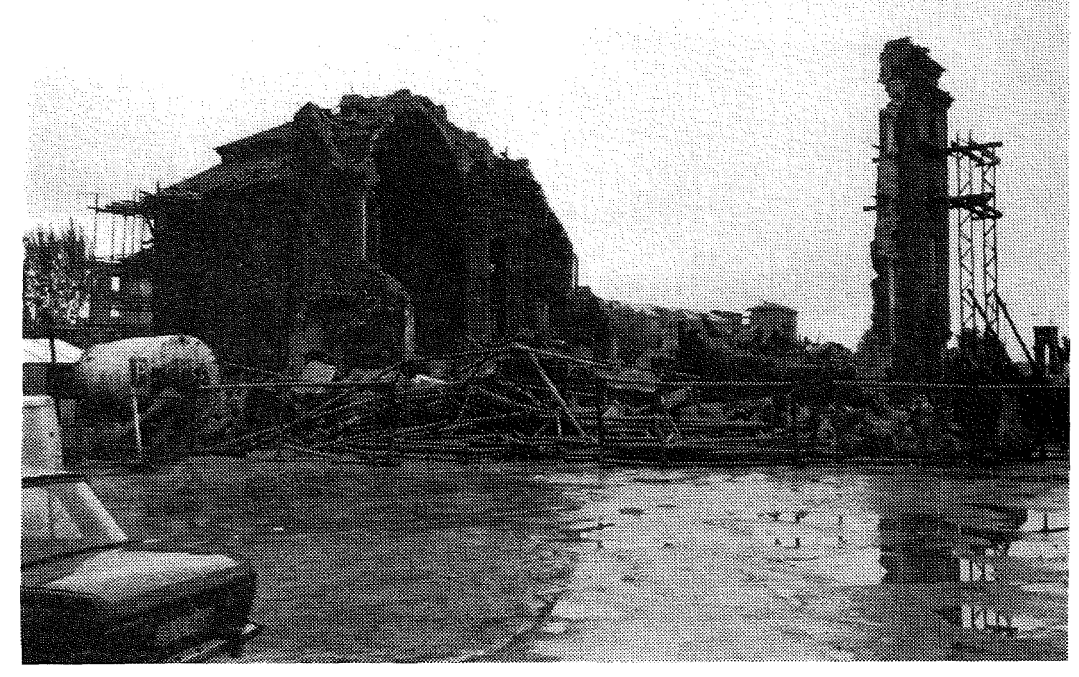

Figure $39 \quad$ Leninakan Cathedral. 


\section{LIFELINE SYSTEMS}

\subsection{General}

Damage to lifeline systems by the earthquake generally appears to have been limited to localised instances. In Spitak, which experienced the higher intensities of shaking, damage to buildings was very severe and services to individual buildings would have been dislocated.

\subsection{Roading}

The roads in the area were paved with asphaltic concrete and kerbs, where present, consisted of black tuff blocks of approximate dimensions of $100 \mathrm{~mm}$ wide, $300 \mathrm{~mm}$ deep and varying between $500 \mathrm{~mm}$ and $1000 \mathrm{~mm}$ long. Movement of these blocks due to the earthquake was not observed during our visit.

In and about Spitak some cracking is reported to have occurred in the paving of the main roads, including some associated with fault rupture. This was subsequently repaired and it appears that road pavements did not require significant work in the aftermath of the earthquake.

\subsection{Power}

The power authority in the Soviet Union is the Ministry of Energetics, with reticulation being the responsibility of local authorities. We were told that specific seismic design standards exist for power stations in the USSR but that no such standards exist for plant and equipment located outside of power stations.

The Armenia Nuclear Power Plant is situated at Oktembryan, about $90 \mathrm{~km}$ from the epicentre. It consists of two $440 \mathrm{MW}$ pressurised water reactors. We were told that this plant was undamaged by the earthquake but was, however, shut down subsequently. This decision was made in Moscow and the reasons given to us were public fear of another Chernobyl event and the costs associated with modifying the plant to meet the post earthquake, higher, seismic design criteria for the area. Details of the plant and the earthquake effects on it are reported by Schiff \& Yanev [Chapter 9 of Wyllie \& Filson, 1989].

It was reported that switching stations in Spitak were badly damaged [Anikolenko, pers. comm.].

At a substation in Leninakan, just north of Lenin Square on the Tbilisi Highway, a 135 tonne transformer jumped off its rails. It is reported that this transformer was secured from sliding with $50 \mathrm{~mm}$ long pins. The seismic switch was tripped. All power was restored within four days.

Many transformers are not anchored to the rails but are secured from rolling only by steel chocks welded to the rails (Figure 40). In one case, a transformer, in Spitak, jumped off its rails. The chocks intended to prevent the transformer from rolling failed to restrain it when the welds failed (Figures 41, 42 and 43).

Some ground mounted transformers were reported to have moved up to $100 \mathrm{~mm}$. Pole mounted transformers appeared to have survived the event.

Power pole design is apparently standardised to two types: reinforced concrete,timber or rail iron ground posts (Figures 44, 45 and 46) and an A-frame pole with timber or reinforced concrete ground posts (Figure 47). Both types have wooden poles secured to the ground posts with wire ties. In Spitak a pole was observed to have failed, but it could not be identified as being a direct result of the earthquake shaking (Figures 48 and 49). High voltage transmission lines are supported on steel lattice type pylons anchored in concrete; these appear to have performed well. A number of power lines were supported on towers fixed to building roofs. Obviously these survived only when the building structures remained standing.

High voltage ceramic isolators also suffered damage.

\subsection{Drainage}

Damage to drainage facilities apparent at the time of our visit appeared to have been limited to household connections. We were told that underground sewerage pipework performed well, although utilisation was reduced through loss of connections and of facilities in collapsed buildings. Schiff \& Yanev [Chapter 9 in Wyllie \& Filson] discuss sewerage system damage claims, including reports that $170 \mathrm{~km}$ of a total of $200 \mathrm{~km}$ of "clay" sewer pipe in the city of Leninakan was totally destroyed. They state that, generally speaking. high ground accelerations in the absence of ground deformation would not cause the reported damage. However, experience from the 1987 Edgecumbe, New Zealand, earthquake shows that damage can occur to buried pipes in the absence of visible ground deformation. The damage in the town of Edgecumbe resulted from significant compressive strains over an area of several square kilometres.

\subsection{Stormwater}

We were told that stormwater drains performed well. A feature of road drainage is that there is no roadside gutter. The road seal butts against the kerb blocks and large (approximately $600 \mathrm{~mm}$ square) stormwater grates are situated adjacent to the blocks. To assist in drainage of stormwater an open channel had been dug against the kerb blocks in at least one street of Spitak (Figure 50). Another feature of Soviet design is that building downpipes are generally not directly connected to the stormwater pipework. Large downpipes ( $100 \mathrm{~mm}$ diameter and greater) spill water onto the footpath adjacent to the building.

\subsection{Public Health}

We were told that, subsequent to the earthquake, pits were dug and covered with timber to serve as toilets until alternative arrangements could be made [R. Goodwin, Red Cross Canada, pers. comm.]. Small amounts of lime were used on these pits where it was available. One toilet facility was available per 100 survivors. In October 1989, 10 months after the earthquake, "long drop" toilets were still in use in parts of Spitak.

A major rodent problem occurred for a period after the event, until enough of a suitable poison enough could be found to control the infestation.

\subsection{Water}

The water supply to the area is from underground springs. Two supplies are reticulated - hot and cold water. 


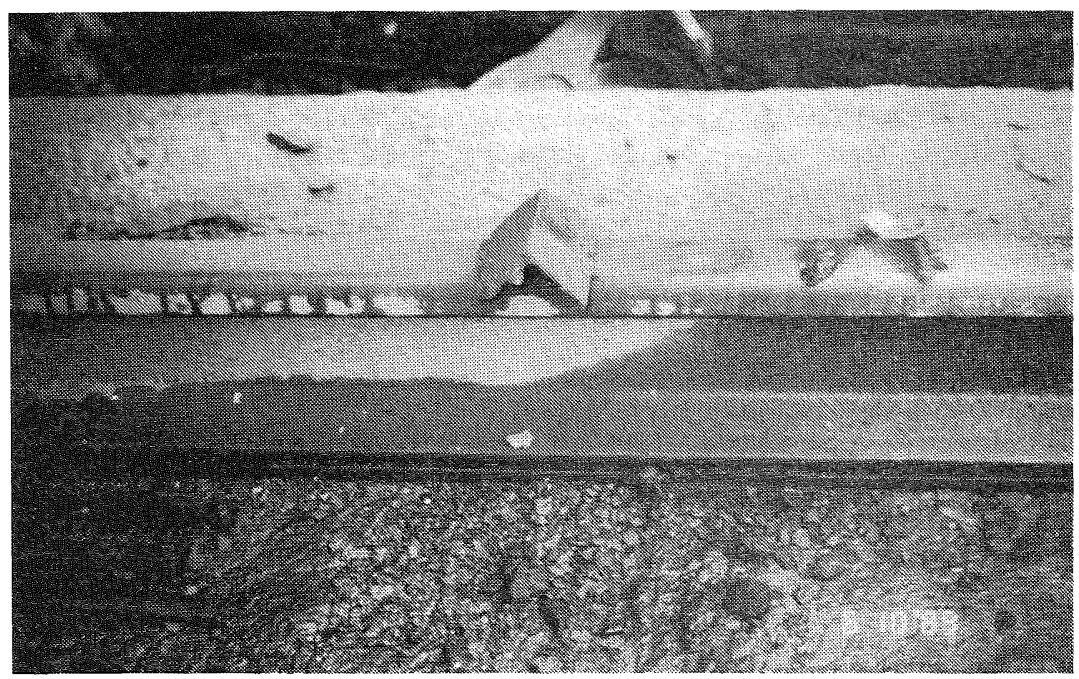

Figure 40 Transformer support rail showing failure of wheel chocks.

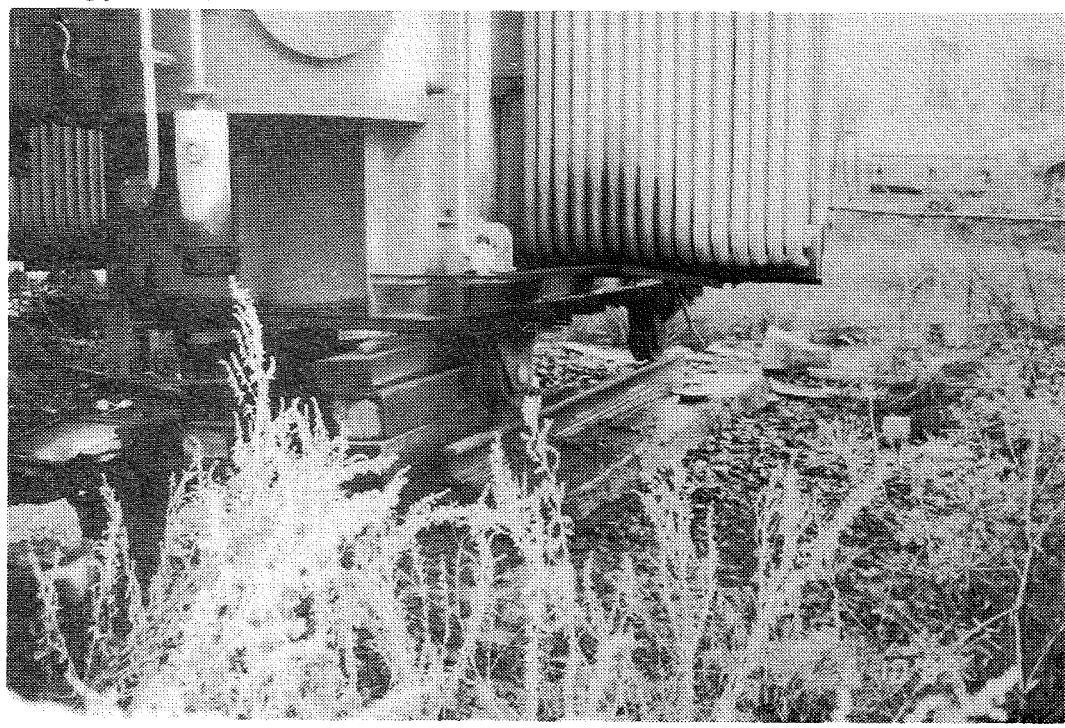

Figure 41 Transformer at Spitak jumped off track

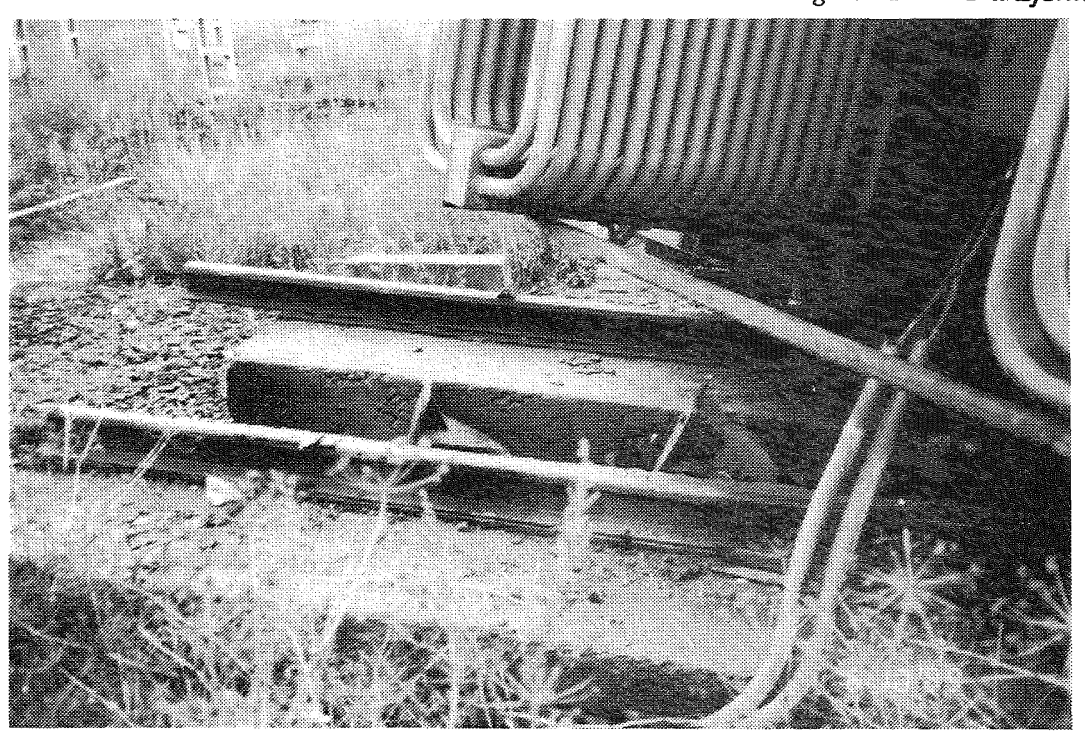

Figure 42 Transformer support foilure at Spitak 


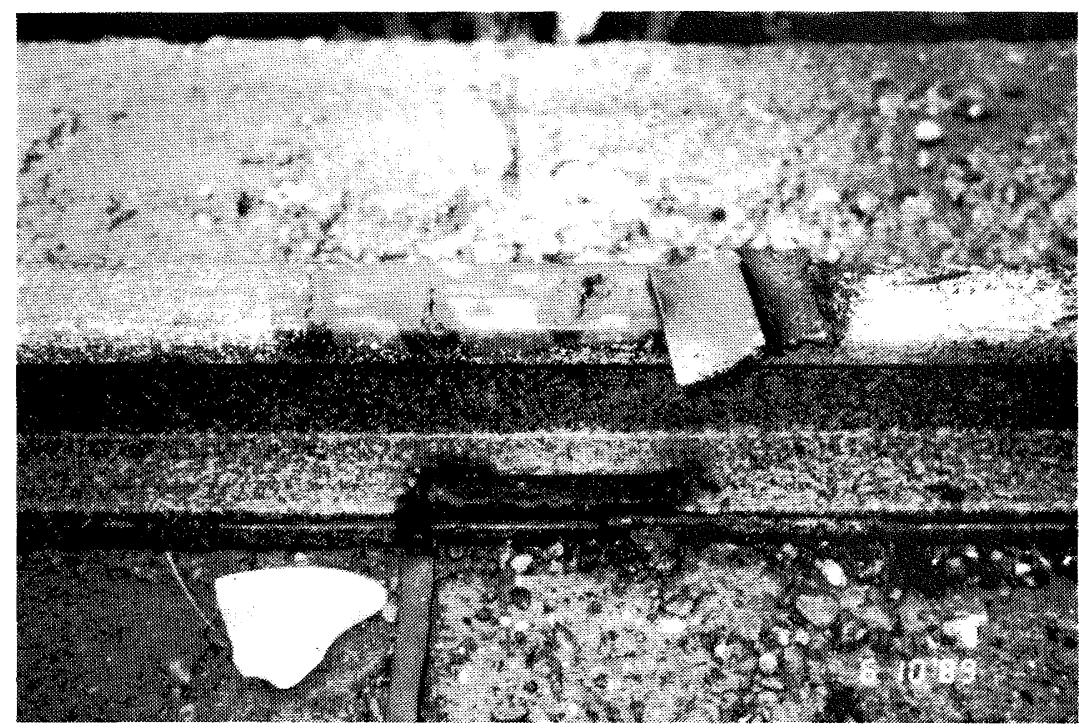

Figure 43 Failed wheel chocks on transformer support rail at Spitak.

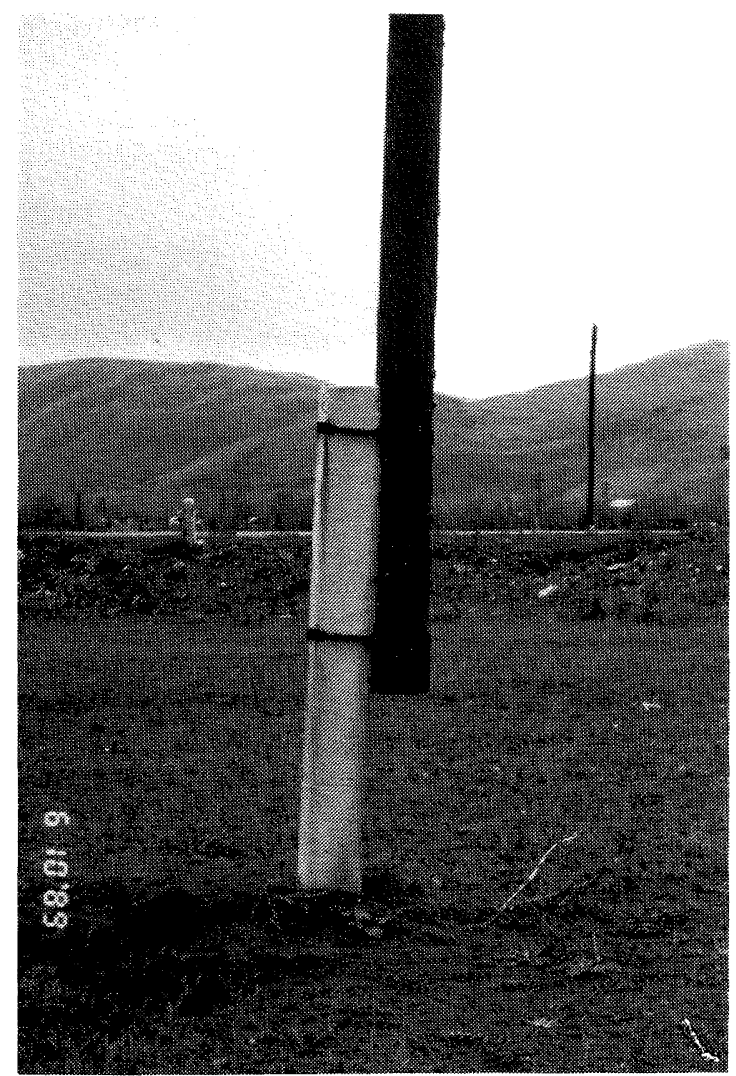

Figure 44
Power pole foxed to precast reinforced concrete ground post.

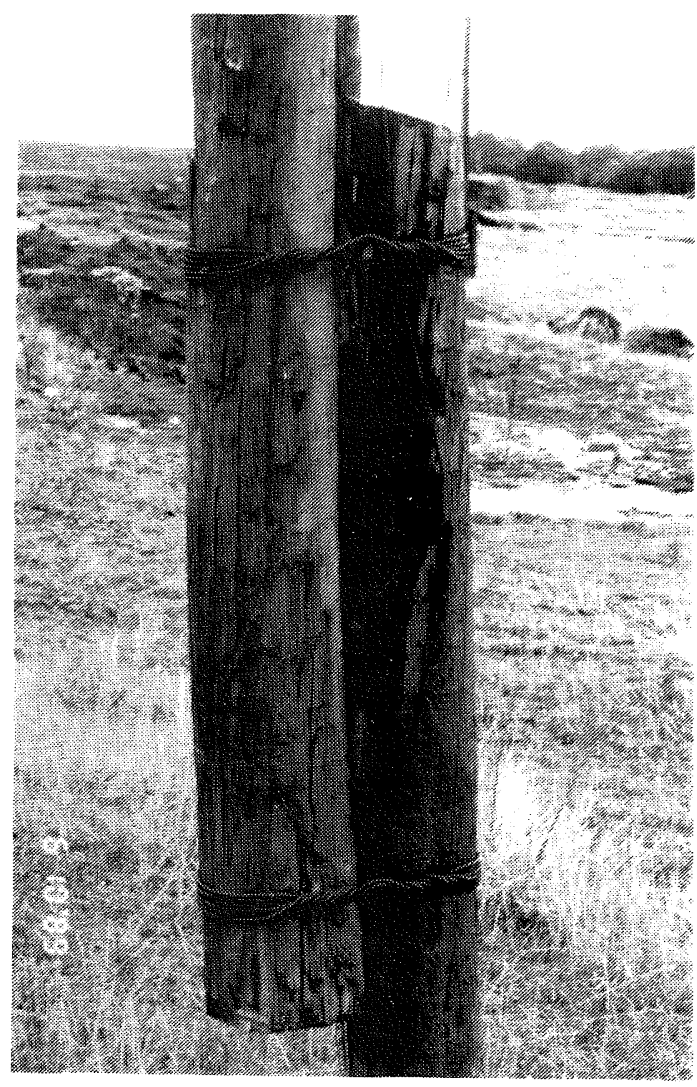

Figure $45 \quad$ Power pole foxed to timber ground post. 
280

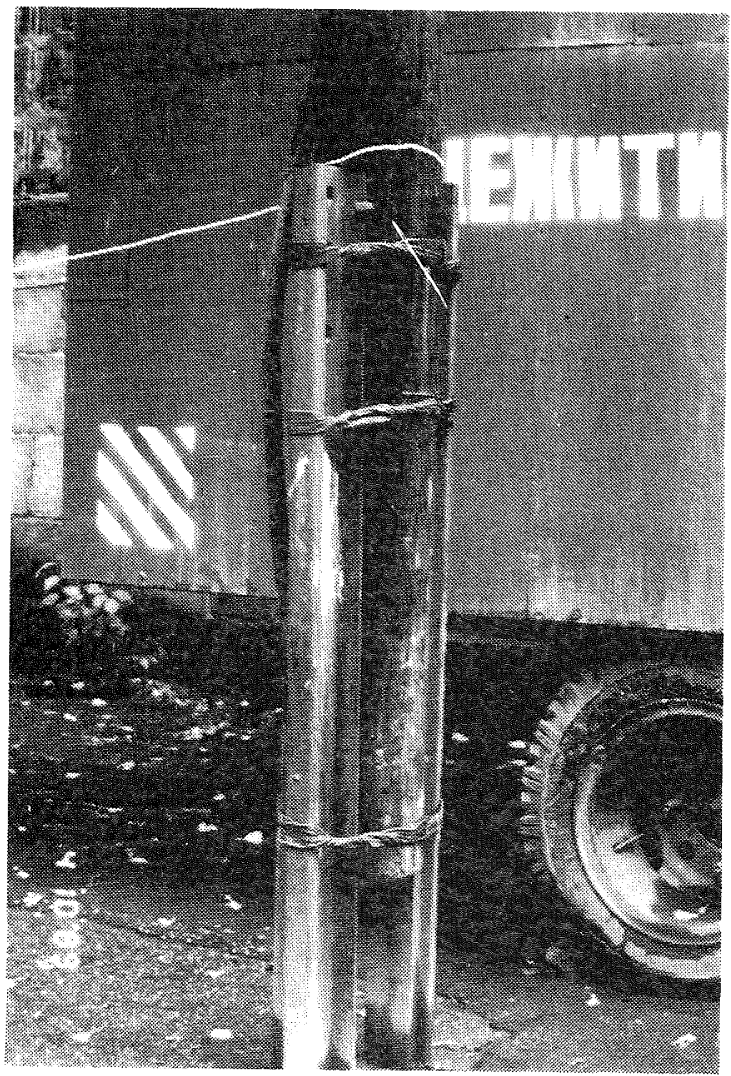

Figure 46 Power pole foxed to steel nail irons cast into pavement.

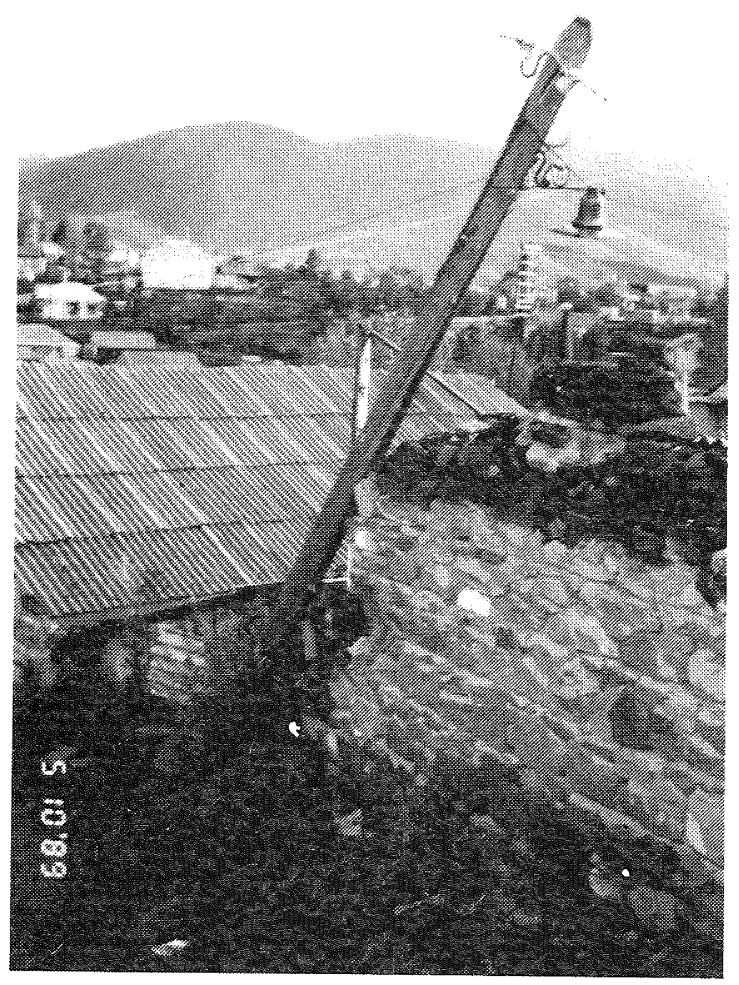

Figure 48 Power pole fixing failure at Spitak.

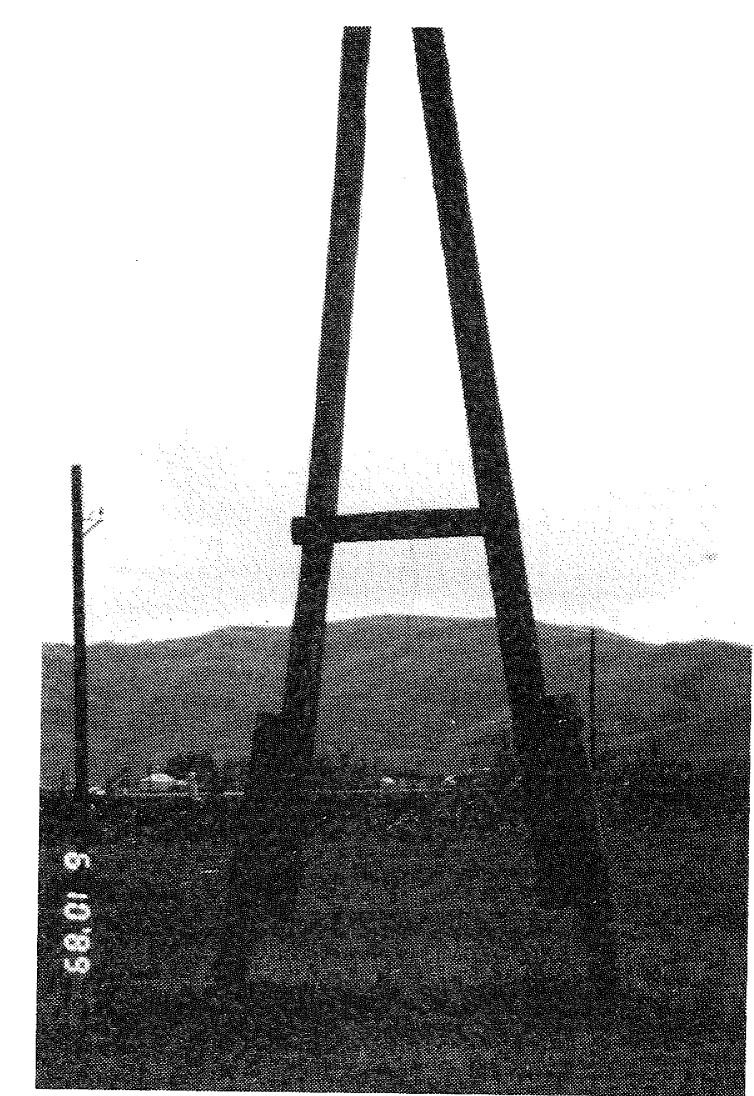

Figure 47 A-frame power pole (not used for local distribution).

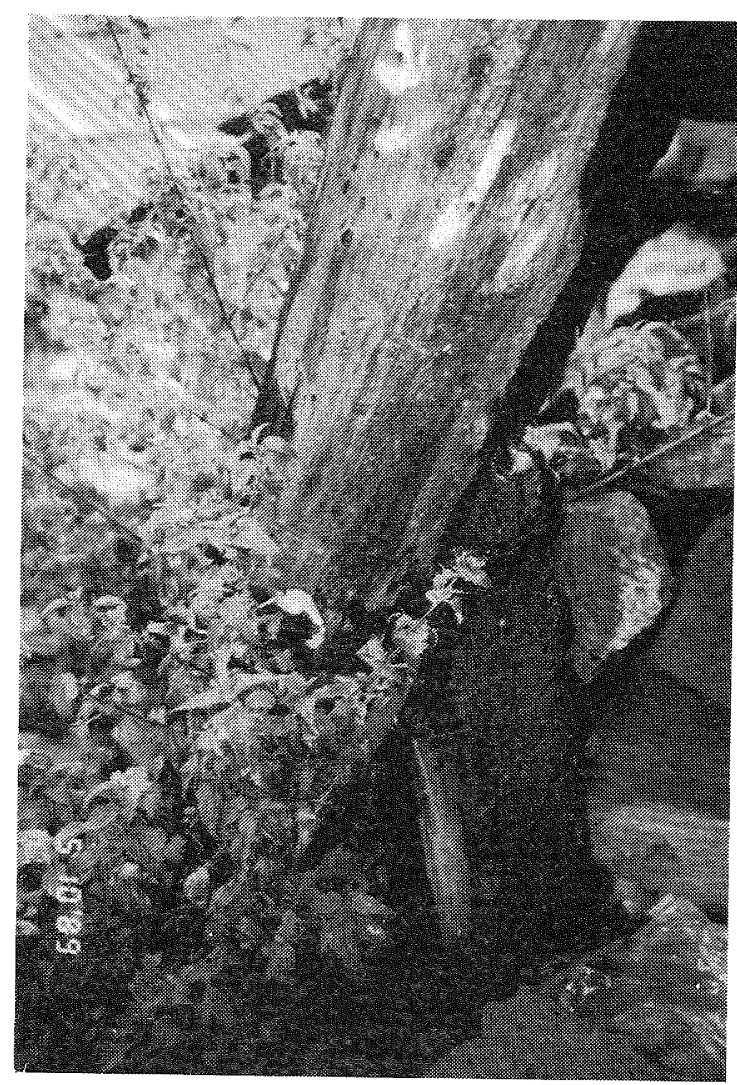

Figure 49 Close up view of power pole faing failure at Spitak. 
As for the damage to other utilities, we were told that underground pipework performed well. Again Schiff \& Yanev (1989) report that this was not the case and that damage did result.

Standpipes were installed on the water mains and were reportedly uncontrolled [R. Goodwin, pers. comm.] Apparently some standpipes were erected without authority. Goodwin reported the all water supplies were to have been tested to determine their potability but this was not always the case. He also reported that latrine holes were set up in close proximity to water supply points - again apparently uncontrolled.

\subsection{Gas}

Natural gas supplied to the area is propane. The underground services reportedly suffered no damage in the earthquake. Damage to building connections caused loss of pressure in the main gas transmission lines in Leninakan. Automatic shut-off valves cut supply when the pressure drop was sensed.

\subsection{Communications}

The main telephone exchange in Spitak was destroyed during the earthquake (Figure 30). By the use of portable microwave stations, military communication was almost fully restored within two days of the earthquake. Some wooden telephone poles broke at rotted bases and at least two steel communication towers on mountain tops collapsed [Schiff \& Yanev in Chapter 9, Wyllie \& Filson, 1989].

\subsection{Railway}

There were instances of significant damage to bridges and to an embankment at Nalband, e.g. the bridge abutment failure described in section 8.1

\section{POST EARTHQUAKE INVESTIGATION}

Post earthquake studies were being carried out by the Soviets and others. We were told of fault mapping, trenching across the surface rupture [Philip et al, 1992], monitoring of postseismic deformation by laser EDM and repeated levelling, as well as ongoing monitoring of seismicity by telemetered seismometers.

\section{RESCUE, RECOVERY AND RECONSTRUCTION}

The Spitak Earthquake occurred at 11:41 hours local time, and people were variously at work, school, cooking midday meals, among other things.

\subsection{Rescue}

Rescue effort was in the first instance by locals, who rescued where they could victims trapped in collapsed buildings Efforts were handicapped by the shortage of equipment and, at night particularly, by the lack of electrical light, bare hands were used for digging. Outside aid came principally from Armenia and other republics of the Soviet Union as well as some specialist rescue teams from UK, USA, France and the GDR - some of which included dog rescue teams. There were some 30,000 persons involved in the rescue phase.

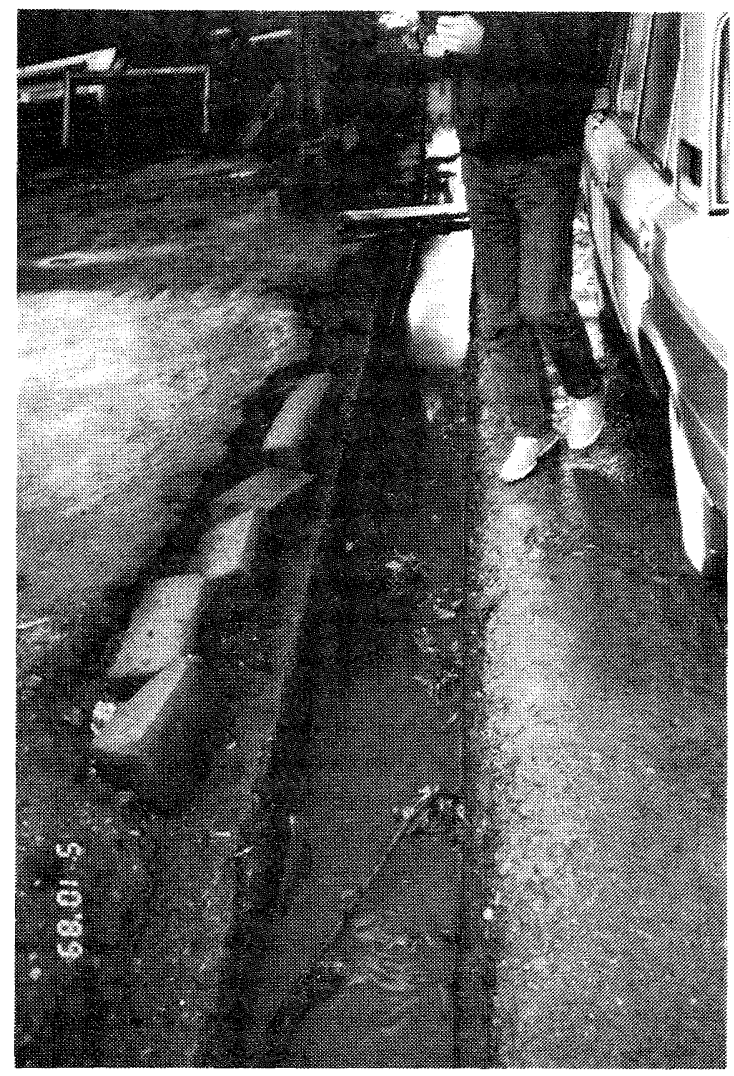

Figure 50 Stormwater channel dug up adjacent to kerb blocks in Spitak.

Some 15,000 people were rescued alive from collapsed buildings. The International rescue teams rescued about 64 persons. The last reported live rescue occurred 19 days after the earthquake. Post recovery deaths resulted from hypothermia, dehydration, and crush injuries.

\subsection{Recovery}

Tent cities were set up to house and feed some 330,000 people, later a variety of refugee camps were constructed (Figure 51), some provided by foreign countries, including Italy, Norway and Switzerland. About 500,000 were made homeless [Demryan et al., 1989]. Tents were still being used at the time of our visit, 10 months after the earthquake.

Some surviving families with children have been accommodated outside the affected region, some outside of Armenia, in Georgia. Such groups include Armenianlanguage teachers [Demryan et al., 1989].

\subsection{Reconstruction}

Reconsideration of seismic zoning has raised the question whether some parts of the region should be rebuilt. Rebuilding has started, following international input into urban planning and site selection. However the relations with the neighbouring republic of Azerbaijan have deteriorated to the extent that building materials, that were railed from the north through Azerbaijan, were not being delivered. Consequently, construction crews from outside 


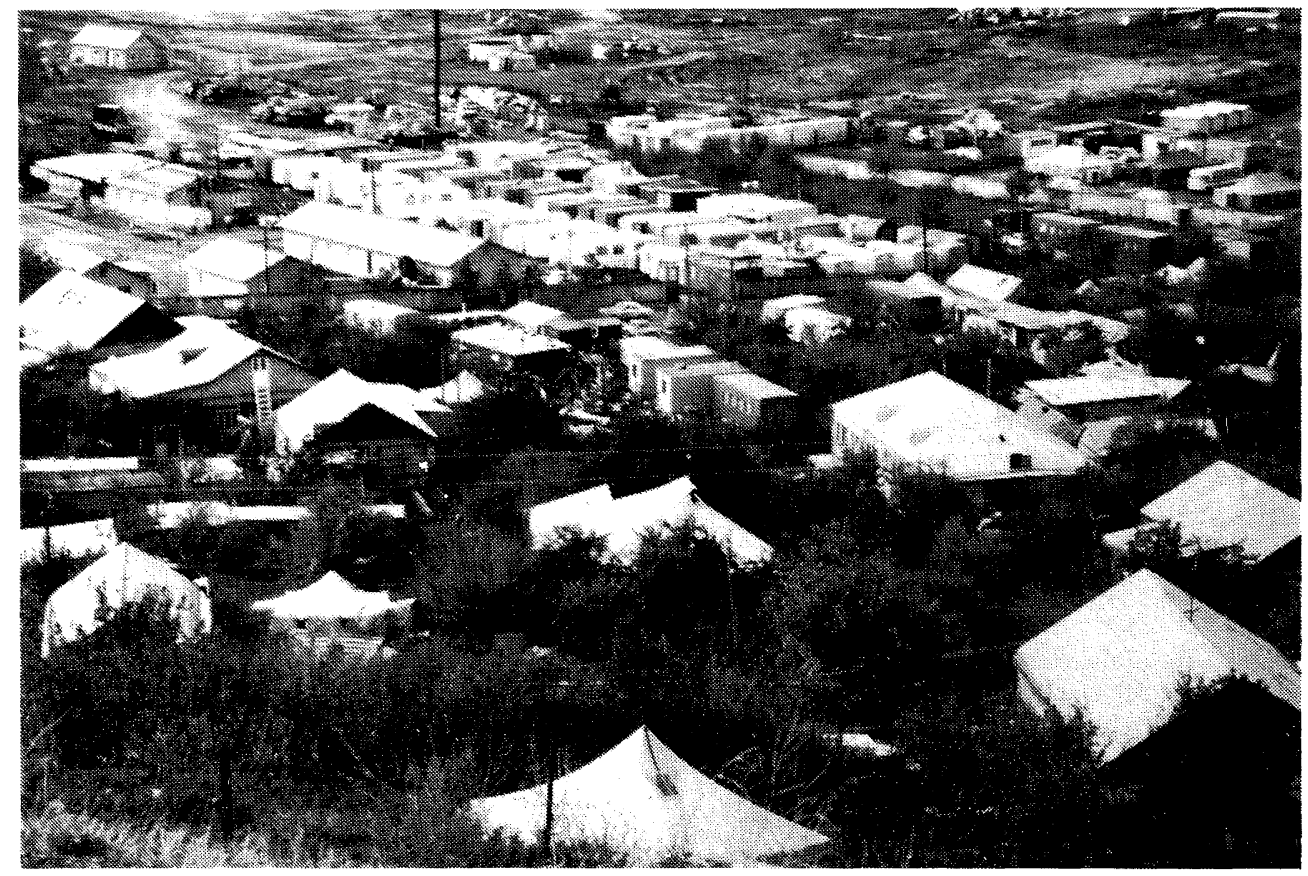

Figure $51 \quad$ Refugee camp.

Armenia were being sent home during our visit as they had insufficient building supplies. International Red Cross staff we met expressed concerns that many people displaced by the earthquake were facing a second winter in tents.

\section{DISCUSSION}

\subsection{Seismic design loads}

Seismic design loads used in the USSR are based on the MSK intensity scale. Design intensities are taken from a zoning map which, just as in New Zealand, has been drawn up from various scientific, engineering and political considerations. An excerpt from the zoning map, for the Caucasus region, is shown in Figure 5. In Table IV design intensities taken from the map are compared with intensities observed in the Spitak earthquake by Soviet scientists.

Bommer and Ambraseys [1989] note that the seismicity of Armenia is not high. The strong shaking experienced in Spitak in December 1988 is indeed a rare event for any given locality, yet when it does occur the effects on the extremely unforgiving, non-ductile structures found in the region are enormous. The devastation seen in Armenia emphasizes the importance of careful detailing for ductility, so that the rare, great event can be survived without catastrophe. The Armenian experience also underlines for us the necessity of detailed inspection and supervision during construction to ensure that ductile design features are implemented correctly.

The Spitak earthquake generated ground shaking intensities up to MSK X. Seismic hazard zoning of the USSR had assigned the region a maximum of VIII. The incorrect zoning, and the poor quality of recent building design, and of materials, have led to the losses from the earthquake, including over 25,000 lives. Some Soviet papers suggest the earthquake could have been predicted, it was not.
New Zealand does not have the population density, nor the form of construction, that led to such a large loss of life from a significant, but not large, earthquake. However there are a number of lessons that New Zealand can learn from this event:-

- Historically, as illustrated by Spitak, damaging earthquakes may occur in any one region at intervals of hundreds of years, the equivalent of many human generations. The Spitak earthquake has demonstrated that ignoring the likelihood of such events, in terms of planning and construction, is extremely costly, both in loss of life as well as property.

- Seismic zoning requires representative data and political will. Revision of zoning must be maintained as advances in knowledge and analytical techniques are made.

- Construction quality assurance practices must be maintained, or improved; poor quality construction was a significant factor in the failure of new buildings in Armenia.

\section{ACKNOWLEDGEMENTS}

The visit to the USSR was by invitation of the Soviet Academy of Science who met all costs within the USSR. The USSR Embassy in Wellington N.Z. was instrumental in making arrangements. Other significant financial support was given, particularly by the New Zealand Earthquake Commission who sponsored the international travel costs, and by the New Zealand National Society for Earthquake Engineering reconnaissance fund.

The employers of all team members granted them special leave to undertake the field investigation. Thus Works 
Development and Services Corporation Ltd, DSIR Geology \& Geophysics, Murray-North Ltd, the University of Canterbury, and The Wellington Regional Council are thanked for their support.

Many individuals and institutions freely gave of information and support. Particular thanks are due to:-

O. Yu. Shmidt, Institute of the Physics of the Earth, Moscow - Professor Alexi Nikolaev, Dr Victor Shteinberg, Dr Igor Beresnev and Dr A.A. Nikonov;

Institute of Geological Sciences, Academy of Science, Yerevan, Armenia - Dr Ashott Karapetian and Dr Arkadi Karachanian;

State Seismological Committee, Moscow Dr Valeri Anikolenko;

Laboratory of Neotectonics and Remote Sensing, Geological Institute, Moscow - Dr Vladimir Tifonov;

Earthquake Engineering Division, Ministry of Construction, Tsukuba, Japan - Dr Kazuhiko Kawashima;

Building Research Institute, Ministry of Construction, Japanese Government - Dr Yoshikazu Kitagawa;

European Earthquake Field Investigation Team (EEFIT), c/Ove Arup, London - Edmund Booth, Greg Jigaher and Antonio Pomonis;

Engineering Seismology, Imperial College, London Professor N.N. Ambraseys and Dr Julian Bommer;

Earthquake Engineering Research Institute (EERI), San Francisco - Susan Tubbesing, Jack Meehan, Christopher Arnold, Charles Scawthorn, Ansell Schiff, Lloyd Cluff and Frank McClure;

Office of Earthquakes, Volcanoes and Engineering, U.S Geological Survey, Menlo Park, California - Dr R.V.Sharp.

Additional very special thanks are due to our Soviet guide, Dr Igor Beresnev, who endured much in enabling us to visit Armenia.

Figures 9 and 15 are taken from Bommer and Ambraseys [1989b] (see references below) and are reprinted by permission of John Wiley \& Sons, Ltd.

Figures 1,3,4 and 17 are taken from Wyllie and Filson [1989] (see references below) and are reprinted by permission of the Earthquake Engineering Research Institute (EERI)

\section{REFERENCES}

AFPS, 1989: Le Seisme de Spitak (RSS d'Armenie) du 7 Decembre 1988, Rapport preliminaire de la Mission, Association Française du Genie Parasismique, Paris.

Ambraseys, N.N., Adams, R., 1989: Long-term seismicity of North Armenia, EOS Vol. 70, No. 10, pp. 145, 152-154.

Bommer, J., Ambraseys, N.N., 1989a: The Spitak (Armenia, USSR) earthquake of 7 December 1988: a preliminary engineering seismology report, Imperial College ESEE/EFTU Research Report 89/1, 84 p.

Bommer, J.J., Ambraseys, N.N., 1989b: The Spitak (Armenia USSR) earthquake of 7 December 1988: a summary engineering seismology report, Earthquake Engineering \& Structural Dynamics, Vol. 18, pp. 921-925.

Borcherdt R.D. (ed), 1989: Results and Data from Seismological and Geologic Studies following Earthquake of December 7, 1988, Near Spitak, Armenia SSR, US Geological Survey Open File Report 89-163A, $188 \mathrm{p}$.

Cisternas, A., Philip, H., Bousquet, J.C., Cara, M., Deschamps, A., Dorbath, L., Dorbath, C., Haessler, H., et al, 1989: The Spitak (Armenia) earthquake of 7 December 1988: field observations, seismology and tectonics, Nature, No. 339, pp. 675-679.

Demryan, A., Vinogradov, A., Milutenko, V., 1989: The Armenian earthquake disaster, Sphinx Press, $241 \mathrm{p}$.

Dowrick, D.J., 1987: Earthquake Resistant Design, Wiley, $519 \mathrm{p}$.

Haessler, H., Deschamps, A., Dufumier, H., Fuenzalida, H., Cisternas, A. 1992: The rupture process of the Armenian earthquake from broad-band teleseismic body wave records, Geophysics Joumal International Vol. 109, pp. 151-161.

Lienberg, Jaschenko, 1989: abstract, Proc. International Symposium on Deformation and Prognosis, Yerevan.

Pacheco, J.F., Eastabrook, C.H., Simpson, D.W., Nabelek, J.L., 1989: Teleseismic body wave analysis of the 1988 Armenian earthquake, Geophysical Research Letters, Vol. 16, pp. 1425-1428.

Philip, H., Rogozhin, E., Cisternas, A., Bousquet, J.C., Borisov, B., Karakhanian, A., 1992: The Armenian earthquake of 1988 December 7: faulting and folding, neotectonics and paleoseismicity, Geophysics Joumal International, Vol. 110, pp. 141-158.

Pomonis, A., 1990: The Spitak (Armenia, USSR) earthquake: Residential Building Typology and Seismic Behaviour, Disasters, Vol. 14, pp. 89-114.

Shephard, R.B., Wood, P.R., Berrill, J.B., Gillon, N.R., North, P.J., Perry, A.K., Bent, D.P., 1990: The Loma Prieta, California, earthquake of October 17, 1989 Report of the NZNSEE Reconnaissance Team, Bulletin New Zealand National Society for Earthquake Engineering, Vol. 23, pp. 1-78.

Trifinov, V.G., Karakhanian, A.C., Kozhurin, A.I., 1989: (Russian), Priroda Vol. 12, pp. 32-38.

Westerway R., 1990: Seismicity and tectonic deformation rate in Soviet Armenia: implications for local earthquake hazard and evolution of adjacent regions, Tectonics, Vol 9, pp. 477-503.

Wyllie, L.A., Filson, J.R., (Eds) 1989: Armenia earthquake reconnaissance report, Earthquake Spectra, Special Supplement No. 89/01, EERI, 175 p. 